Linköping Studies in Science and Technology

Licentiate Thesis No. 1822

\title{
How do biogas solutions influence the sustainability of bio-based industrial systems?
}

Linda Hagman

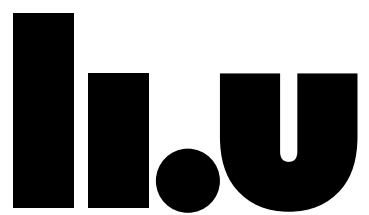

LINKÖPING UNIVERSITY

Environmental Technology and Management

Department of Management and Engineering

Linköping University, SE-581 83, Sweden

Linköping 2018 
(C) Linda Hagman, 2018

Institution: IEI/ Industriell Miljöteknik

ISBN: 978-91-7685-198-2

ISSN 0280-7971

Printed in Sweden by LiU-Tryck, Linköping, 2018

Cover Design: Linda Hagman

Distributed by:

Linköping University

Department of Management and Engineering

SE-581 83 Linköping, Sweden 
Till min älskade familj 



\section{ABSTRACT}

Biomass is a valuable and limited resource that should be used efficiently. The potential of replacing fossil-based products with bio-based ones produced in biobased industrial systems is huge. One important aim of increasing the share of biobased products is to improve the sustainability of systems for production and consumption. Therefore, it is important to evaluate what solutions are available to improve the sustainability performance of bio-based industrial systems, and if they also bring negative impacts. The thesis focuses on assessing the role of biogas solutions in developing sustainable bio-based systems. Such assessments are often quite narrow in their scope and focus on quantitative environmental or economic aspects. This thesis aims at also including feasibility related aspects involving the contextual conditions that are assessed more qualitatively. Biogas solutions are identified as a versatile approach to treat organic materials which are generated in large volumes in bio-based industrial systems. The results show that biogas solutions in bio-based industrial systems (i) improve circular flows of energy and nutrients, (ii) are especially viable alternatives when the quality of the by-product streams become poorer, and (iii) may improve the profitability of the bio-based industrial system. To perform better assessments of these systems, it seems valuable to broaden the set of indicators assessed and include feasibility-related indicators, preferably through the involvement of relevant stakeholders as they contribute with different perspectives and can identify aspects that influence the sustainability in different areas. Future studies could benefit from applying those broader assessments on more cases to build on a more generalisable knowledge base.

Keywords: biogas, biorefinery, biomass, circular bioeconomy, sustainability, feasibility, stakeholders, assessments, methods 


\section{ACKNOWLEDGEMENTS}

The beginning of this journey took place in the summer of 2015. Crazily enough, I was chosen to research biogas solutions in industrial settings. My biggest thanks goes to Mats Eklund and my other colleagues responsible for employing me. Mats, together with Niclas Svensson, have been my excellent supervisors and coached me in the right direction when I was unclear or lost. I thank Energimyndigheten, partners to the Biogas Research Center and Linköping University for funding this exciting research.

I also want to thank everyone at Environmental Technology and Management, present and absent, for being the best colleagues someone could have. Special thanks goes out to everyone I have had the honour to share a room with, as well as the most important employee at the division, Maria Eriksson. Thank you, Maria, for keeping all of us on the right track.

The most important thank you goes to my beloved husband, Rikard Hagman, who makes every day wonderful. You are the steady rock who always supports me and takes care of me. Thanks to us we have not only been given Albert but another baby on the way, and there is no greater gift in life than that. I love you! 


\section{LIST OF APPENDED PAPERS}

I. Hagman L., Blumenthal A., Eklund M., Svensson N., (2018)

The Role of Biogas Solutions in Sustainable Biorefineries In Journal of Cleaner Production.

The first author was responsible for researching the agricultural and aquacultural industrial systems described in this article. The first author has a major role in assembling the paper.

II. Hagman L., Eklund M., Svensson N., (Submitted)

Assessment of By-product Valorisation in a Swedish Wheat-based Biorefinery, To Waste and Biomass Valorization.

The first author was responsible for this research project and developed the methodology used, in conversation with supervisors. The first author wrote most of the article with valuable inputs from the other authors.

III. Hagman L., Feiz R. (draft), Assessing the Sustainability of a Swedish Wheat-ethanol Biorefinery through a Method Focusing on Feasibility and Life Cycle Performance.

The first author together with Roozbeh Feiz developed the multicriteria framework which the first author then applied to a specific case. The first author wrote the article together with Dr. Feiz. 


\section{CONTENTS}

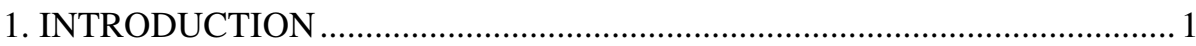

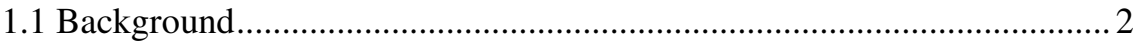

1.2 Aim and research questions ...................................................................

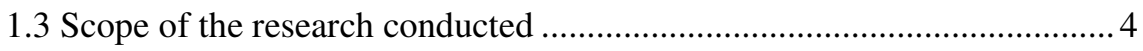

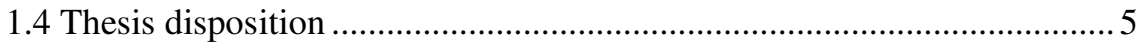

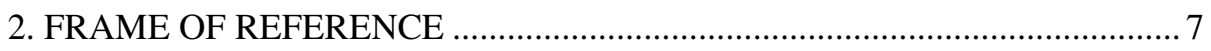

2.1 Sustainability system analysis of bio-based industrial systems ................ 8

2.2 Biorefineries - Value from biomass ...................................................... 9

2.3 Biogas solutions- Anaerobic biomass treatment ...................................... 11

2.4 Overlaps between the research fields ..................................................... 12

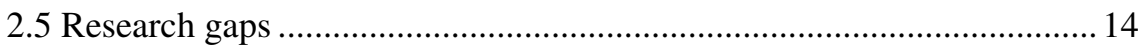

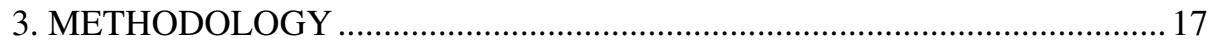

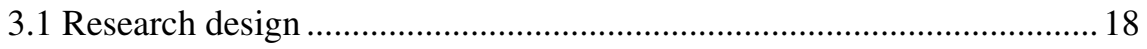

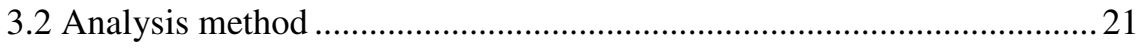

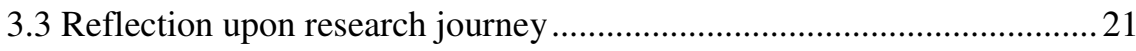

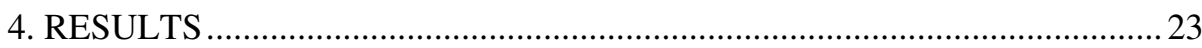

4.1 Circular flows ................................................................................... 24

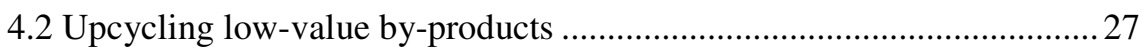

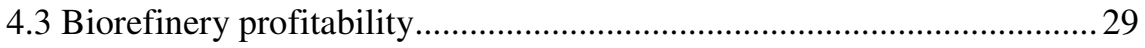

4.4 Better-informed decision-making........................................................... 30

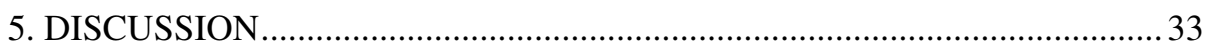

5.1 The contribution of biogas solutions to sustainability in bio-based

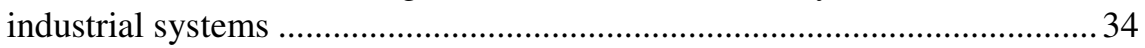

5.2 Creating assessments for decision support regarding development scenarios in bio-based industrial systems....................................................... 38

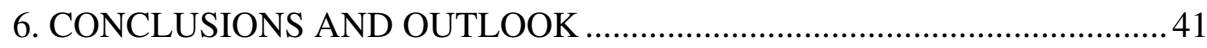

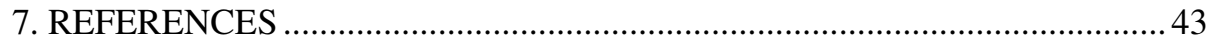

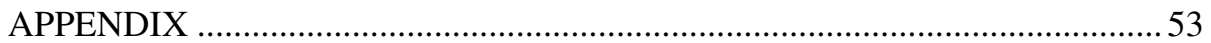




\section{LIST OF FIGURES}

Figure 1. Illustration of the thesis disposition consisting of introduction, frame of reference, methodology, results, discussion, and conclusions.

Figure 2. Scopus search for overlaps between research areas. The number of hits is presented for each research area and the overlaps. In parentheses are the results when "system analysis" replace "sustainability system analysis" as a search term.

Figure 3. Illustration of each article's contributions to the research questions....20

Figure 4. Illustration of the method for choosing the analysis topics. 21

Figure 5. Different topics identified from the result and discussion chapters in the appended articles. 24

Figure 6. Modified version of the Eco-pyramid, including upcycling possibilities as a complement to cascading. Presented in Hagman et al. 2018 (Article I).......28

Figure 7. Financial results of Article II, normalised to illustrate the relation between the scenarios (Hagman et al., submitted 2018). Fodder and local biogas as fuel provide the same net income to the biorefinery. Incineration is the most costly alternative. 30

\section{LIST OF TABLES}

Table 1. Summary of Articles I, II and III, where the background, aim, system boundaries, methods, results and conclusions are presented

Table 2. Alternative treatment methods for biomass evaluated based on nutrient, energy and waste water management. 


\section{INTRODUCTION}

This chapter introduces the platform for understanding why this thesis focuses on biogas solutions in bio-based industrial systems and their position within the circular bioeconomy. The aim and research questions, which will guide the research in this thesis, are also found in this chapter. It will end with the research scope and thesis disposition. 


\subsection{Background}

The challenges of negative environmental impact due to fossil-based products and inefficient resource use require new ways of thinking and acting. Bio-based industrial systems use raw materials from biomass as their input and refine them into products either in the same facility or in collaboration between different industries. Biorefineries are often referred to as industrial plants which extract valuable products from bio-based raw materials (Cherubini, 2010), whereas bio-based industrial systems are broader and can include producers of single products and industrial networks. Both biorefineries and bio-based industrial systems can have diverse product portfolios, feedback loops and reuse by-products. Biorefineries, or biobased industrial systems, fit well into the circular bioeconomy.

Circular and bio-based economies are two ways of moving towards a more sustainable future. Sustainable development is defined as "development that meets the needs of the present without compromising the ability of future generations to meet their own needs" (WCED, 1987). The circular economy aims at improving sustainability by closing flows throughout material life cycles through increased reuse and recycling (European Commission, 2015). The circular economy is a response to the linear system where products are produced, used and then become waste, which has been common for the last century (NL Government, 2016). The bio-based economy, or bioeconomy, replaces fossil-based products with bio-based products while assuring sustainable resource extraction (European Commission, 2012). There is already today the production of biofuels replacing oil-based fuels, biogenic chemicals replacing those from fossil sources, and even plastics being created from bio-based sources. Combining the two economic strategies results in a circular bioeconomy, which does not only produce bio-based products but tries to use the resources efficiently by extracting several products from a single biomass type and assuring the use of by-products and minimising waste (Carus and Dammer, 2018).

Improving a bio-based industrial system's performance further, valorising byproducts to higher valued products, and upcycling may become more important in future scenarios to improve resource efficiency. Resource-efficient systems can be more sustainable if more products are extracted from the same amount of biomass. One way of upcycling by-products in bio-based industrial systems is biogas solutions (Martin and Eklund, 2011). Biogas solutions are combinations of products and services such as biogas for fuel or energy generation, biofertiliser, waste and waste water management or pretreatment of biomass, all achieved through anaerobic digestion (Wellinger et al., 2013). The biogas solution can contribute with internal energy generation and widen the product portfolio for bio-based industrial systems. Biogas solutions are versatile valorisation methods, as they can treat many different kinds of organic material flows while still producing biogas and biofertilisers (Mountraki et al., 2016). A wide range of benefits with biogas solutions have been identified and studied in the scientific literature (Hagman and 
Eklund, 2016). Some examples are renewable energy sources, accessible nutrients, hygienisation of waste and developing rural areas. One potential drawback with biogas solutions can be technology lock-in for the industry applying biogas solutions to its facilities (Atkinson et al., 2007). If handled poorly, there is a risk for methane leakages in several steps connected to the biogas solution, but the major emissions risk is from digestate storage if no actions to decrease emissions are made (Wellinger et al., 2013). Eutrophication problems have, in some cases, been identified from the biofertiliser (Crolla et al., 2013).

The biofertiliser retrieved from biogas solutions is a nutrient-rich, but wet, replacement for mineral fertilisers. The production of mineral fertilisers is in many ways unsustainable. The fertiliser component phosphourus $(\mathrm{P})$ requires mining from phosphate rock reserves, potassium $(\mathrm{K})$ is mined from potash reserves, and atmospheric nitrogen $(\mathrm{N})$ is fixed by the Haber-Bosch process. Both $\mathrm{P}$ and $\mathrm{K}$ are finite resources which cannot be substituted by other nutrients, and the $\mathrm{P}$ reserves may be exhausted as soon as the next century (Cordell et al., 2009). The stocks for P are mainly limited to four countries in the world (Vaccari, 2009), which means that to become more self-sufficient it will be necessary to recover $\mathrm{P}$ from the biomass sources that exist today. $\mathrm{K}$ is available in large quantities in certain waste materials, e.g., sugar cane and beet processing, spent grains, yeast, and manure, and estimations are that global demand could be satisfied by recirculating $\mathrm{K}$ from waste biomass, if done to a greater extent (Batstone et al., 2015). $\mathrm{N}$ is not a limited resource such as $\mathrm{P}$ and $\mathrm{K}$, but the process for converting nitrogen gas $\left(\mathrm{N}_{2}\right)$ to nitrogen minerals like $\mathrm{NH}_{3}$ is highly energy demanding (Galloway et al., 2004). Biofertilisers replacing mineral fertilisers may, therefore, improve sustainability.

To be able to support decision-makers when new sustainable bio-based projects are considered, broad assessments are required. The assessments need to handle a variety of inputs, outputs, and fluxes while considering a range of impact areas on internal and external systems. Many of the studies today cannot handle the complexity of sustainability in bio-based industrial systems. Some studies focus on techno-economic assessments of bio-based industrial systems providing, for example, potential studies and economic viability of specific scenarios (see Höltinger et al., 2014). Other studies focus on the environmental impact of bio-based industrial systems and particularly, climate impact (Martinez Hernandez, 2013). To aid decision-makers, the tool should structure information, perhaps in a multi-criteria framework where both qualitative and quantitative aspects can be assessed (Feiz and Ammenberg, 2017). For decision-makers, there are not only sustainability aspects which are important; the feasibility, the possible realisation of a project, also needs to be assessed. 


\subsection{Aim and research questions}

Based on the above, the aim of this research is to understand how biogas solutions can influence the sustainability of bio-based industrial systems.

This research wants to establish the potential role that biogas solutions may have in bio-based industrial systems to contribute to sustainability and thus create longlasting systems which do not affect the environment, economy or social issues negatively.

The presented aim is operationalised through the following research questions:

RQ1: How can the valorisation of biomass through biogas solutions contribute to sustainable bio-based industrial systems?

Biogas solutions can be applied to bio-based industrial systems such as waste management, an energy solution or be a part of the pre-treatment. The sustainability of biogas solutions in bio-based industrial systems is compared to other alternative treatments.

RQ2: What is desired in an assessment method to support decision-making regarding by-product valorisation, such as biogas solutions, in bio-based industrial systems?

Methods for assessing by-product valorisation in bio-based industrial systems often lack a broader perspective. It is important to investigate what aspects are required to study in a method to discover feasibility and external impacts from, in this case, biogas solutions in bio-based industrial systems.

\subsection{Scope of the research conducted}

This study is based on Swedish cases. This is to facilitate interviews with engaged actors and the possibility for study visits. The cases picked cover three major biomass sectors, agriculture, forest and aquaculture but more thorough assessments have been made on the agricultural case.

Industries working with biomass valorisation are included in this study and they are called bio-based industrial systems. This term can include networks of companies valorising biomass into one or more products. In this thesis, industries producing several products from the same biomass are included.

The assessments performed aim at including all sustainability aspects, to show how we broaden from especially environmental assessments. Still, there is a heavier weight on environmental aspects, while economic assessments are limited to the profitability of the bio-based industrial system, and social aspects connect mainly to public opinion and effect on society due to environmental impacts. 


\subsection{Thesis disposition}

This thesis consists of six chapters, where the content is illustrated in Figure 1.
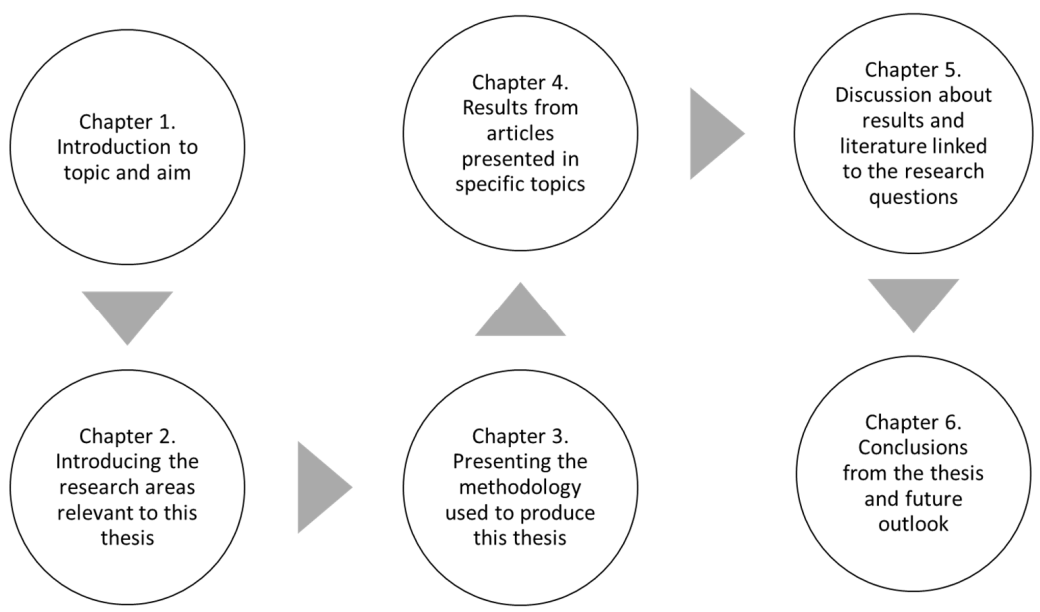

Figure 1. Illustration of the thesis disposition consisting of introduction, frame of reference, methodology, results, discussion, and conclusions. 
HOW DO BIOGAS SOLUTIONS INFLUENCE THE SUSTAINABILITY OF BIO-BASED INDUSTRIAL SYSTEMS? 


\section{FRAME OF REFERENCE}

This chapter presents the theoretical foundation required for the understanding of this thesis. The research areas in focus are sustainability system analysis, biorefineries and biogas solutions. Concepts and terminology for each research area will be presented and overlaps between the research areas identified. The last section describes the research gaps which the author aims to fill through this thesis. 


\subsection{Sustainability system analysis of bio-based industrial systems}

Sustainability system analysis is not a widely used term. Some research connected to system analysis of sustainability is seen in Diwekar (2017), who describes the importance of optimisation in sustainability system analysis which is often applied to future scenarios. The idea of sustainability system analysis in bio-based industrial systems is to broaden assessments from an environmental perspective to a sustainable perspective where economic and social aspects also are studied in development projects for bio-based industrial systems. When bio-based industrial systems are assessed in scientific research, there is often an economic or technoeconomic focus (see Nitzsche et al., 2016; Giwa et al., 2018). Life Cycle Assessments (LCAs) seem to be a common method for evaluating environmental issues in bio-based industrial systems (see Cherubini et al., 2009; González-García et al., 2011). In several of the environmental assessments done on bio-based industrial systems, such as biofuel production sites, the main focus is on climate impact (Lazarevic and Martin, 2016). Climate impact is frequently discussed in society and is important to evaluate, but sustainability assessments need to include more local environmental and social issues, resource use, feasibility issues and economic aspects (Munda et al., 1994) when assessing bio-based industrial systems. Sustainability system analysis can, therefore, improve today's assessment by broadening not only evaluated aspects but also study value chains through a life cycle perspective.

The life cycle perspective is important in LCAs, which have been used for assessing the environmental impact of bio-based industrial systems. There are standards for how an LCA shall be set up (ISO, 2006). An LCA includes not only the impact from the specific facility studied but can also include raw material production, use phase and waste management of a product. The first step is to set up the goal(s) and scope of the study. A functional unit is chosen to make the results more comparable, and can in bio-based industries rely on tonne biomass input or $\mathrm{kg}$ product output (Ahlgren et al., 2015). System boundaries are important to define at this step. The next step is to collect data and create an inventory analysis, while the last step is to study the impact of the case. Depending on what aspects have been chosen to look at, it can range from greenhouse gas emissions to eutrophication to toxicity. Through the whole process, interpretation is done and LCA is seen as an iterative process (ISO, 2006). The downside is that LCA requires a lot of data gathering, and the results can easily be managed due to individual decisions regarding functional unit, system boundaries or allocation method (Ahlgren et al., 2015). There are today attempts to broaden LCA to life cycle sustainability assessments (LCSA), which combines life cycle costing (LCC) and social-life cycle assessments (s-LCA) with LCA (Kloepffer, 2008). Still, the focus is mainly on quantitative aspects, and the methods for assessing the different areas are relatively set. 
An alternative is then integrated life cycle sustainability assessment (ILCSA) presented by (Keller et al., 2015), which proposes the inclusion of more qualitative aspects such as bureaucratic hurdles, risks, infrastructure, and feedstock availability. They also propose that a variety of methods can be used to respond to the different aspects. LCA is often used for assessing bio-based industrial systems. To broaden the method, more sustainability aspects should be included, and a multicriteria approach would add to the life cycle perspective.

The indicator-based tool, Multi-Criteria Assessments (MCA), can apply both quantitative and qualitative aspects onto a case, where several future development scenarios are evaluated to ease decision-making (Buchholz et al., 2009). Commonly, MCA consists of a problem definition, identifying scenarios, defining criteria and indicators, weighting and recommendations, although there is no outspoken standard for MCA (Feiz and Ammenberg, 2017). With MCA, it is possible to widen the scope due to the qualitative indicators which can evaluate aspects such as feasibility, barriers and long-term strategies of different alternatives. In bio-based industrial systems, it can be necessary to handle a wide range of aspects to aid decision-making. It is therefore important to assess the feasibility and riskrelated aspects of alternative development scenarios of a product or an industry (Keller et al., 2015). Another important aspect of MCA is the stakeholder perspectives (Buchholz et al., 2009; Turcksin et al., 2011). Stakeholder perceptions can be important regarding the direction of an MCA and to provide support for decisionmakers (Huang et al., 2011). Decision support is needed for future development scenarios and is connected to uncertainties, which means barriers are an important aspect to evaluate (Keller et al., 2015) in future bio-based industrial systems. MCA can be a tool for creating this kind of decision support, but still, there is no consensus in what aspects need to be evaluated.

\subsection{Biorefineries - Value from biomass}

Biorefineries are an example of bio-based industrial systems which create value from biomass by producing a spectrum of products (Cherubini, 2010). The definition as per the International Energy Agency (IEA) is the "sustainable processing of biomass into a spectrum of marketable products (food, feed, materials and chemicals) and energy (fuels, power, heat)" (Sonnenberg et al., 2007, p. 2). The idea is that biorefineries produce renewable and bio-based materials which can replace fossil products and thus contributes to the bioeconomy (Sauvée and Viaggi, 2016). Biorefineries can process the biomass through several technologies, be they mechanical, chemical and biotechnological (Kamm and Kamm, 2004). There are biorefineries within several different biomass sectors. The three largest sectors are agriculture, forestry and aquaculture, and it is possible to similarly count wastes as a separate sector (Paul Arwas Associates, 2005).

Several articles about biorefineries study biofuel production facilities which valorise their by-products, giving the facility a biorefinery approach (de Jong et al., 
2013). There are identified biorefineries in all three biomass sectors mentioned earlier. In the agricultural sector, ethanol production and by-product valorisation from crops, such as wheat or maize is common (see Wood et al., 2013; Orts and McMahan, 2016). In the aquatic sector, oil-rich algae is used for biodiesel production (see Andersson et al., 2014). While in the forest sector there are examples of biorefineries producing wood, bio-foams and bioenergy (González-García et al., 2016). Technologies within biorefineries develop quickly. It can be technologies for handling new biomass sources, for example, red grape pomace (Martinez et al., 2015), straw (Ekman et al., 2013) or food waste (Dahiya et al., 2018; Haddadi et al., 2018). There is the ability to extract more high-value products from, for example, waste-activated sludge (Zhang et al., 2018) or food waste (Pfaltzgraff et al., 2013). Biorefinery research does not only study existing biomass feedstock; there are several assessments of future potential biomasses to use in biorefineries as well. Some examples are lignocellulosic materials, which have been hard to treat earlier due to big molecules ( FitzPatrick et al., 2010; Luo et al., 2010; ArevaloGallegos et al., 2017); grass-based raw materials (see Kamm and Kamm, 2007; Höltinger et al., 2014); and waste flows (see Chen et al., 2018; Qadeer et al., 2018). Biorefineries are versatile and diverse production facilities with a range of potential biomasses to treat through several different technologies. This results in potential by-product and waste water streams which may need multiple treatments.

Biorefineries have an important role towards a circular bioeconomy (Wagemann, 2012), and some research identifies biorefineries as a strategy towards the circular bioeconomy, as the replacement of fossil products while producing new products more efficiently and improving sustainability (Dahiya et al., 2018). Producing things efficiently can be illustrated with the eco-pyramid by Langeveld et al. (2012). Biorefineries should aim at producing high-value products first even though they are in small amounts, but low-value products which come in larger volumes should also be included in the product spectra of a biorefinery. In the biorefinery research, there is an increased focus on studying the importance of valorising biomass and by-products (see ElMekawy et al., 2013; Kouhia et al., 2015). To be more successful, it can be helpful for a biorefinery to have its own energy recovery to reduce external energy demand as there are often energy-intense processes (Wagemann, 2012). Another important aspect for biorefineries is the possibility of recirculating nutrients (Carey et al., 2016), as they work with biomass. Biorefineries seem to be important for the pathway towards the circular bioeconomy, as long as biomass resources are retrieved in a sustainable manner (Posada and Osseweijer, 2016). Still, there are several areas for improvement regarding resource efficiency and by-product valorisation in biorefineries.. 


\subsection{Biogas solutions- Anaerobic biomass treat- ment}

Biogas solutions can be a range of services and products and can treat a large variety of organic materials, often called substrates. Biogas is produced when organic materials are digested to methane and carbon dioxide during anaerobic circumstances and temperatures ranging from 32-57 degrees (Wellinger et al., 2013). The anaerobic process within the so-called digestion chambers is extremely complex, and the microbial communities are important for the gas exchange ratios. There are several abiotic and biotic factors which either inhibit or enhance the gas exchange (see Shakeri Yekta et al., 2017; Westerholm et al., 2018). The microorganisms can treat a variety of substrates in the digestion chambers. One important aspect for the microbial community is the $\mathrm{C} / \mathrm{N}$ (carbon-nitrogen) ratio of the incoming substrates and therefore co-digestion, mixing several substrates, is preferable (Surendra et al., 2015). The unprocessed gas retrieved from the digester can be called raw gas. Raw gas can be burnt and used for the generation of electricity and heat. The raw gas can be upgraded by removing carbon dioxide and other minor contaminants, and can then be used in natural gas grids or as vehicle fuel (Wood et al., 2013). When the gas is upgraded to 97\% (Bauer et al., 2013), it is called biogas or biomethane.

Biogas solutions are more than just biogas production. After digestion, organic materials remain which have become a nutrient-rich slurry, often called digestate, or biofertiliser when applied as fertiliser (Wellinger et al., 2013). This nutrient-rich biofertiliser is considered to not only contribute with the nitrogen $(\mathrm{N})$, potassium $(\mathrm{K})$ and phosphorus $(\mathrm{P})$ required by plants; biofertilisers, in addition, contain micronutrients and soil organic carbon which helps soils to become more resilient and resistant towards changes in the environment (Alburquerque et al., 2012; Barbosa et al., 2014; Wentzel and Joergensen, 2016). Biofertiliser, therefore, has the potential to replace mineral fertiliser (Tambone et al., 2010). Soils applied with biofertilisers seem to bind carbon dioxide into the soils and thus reduce the concentration in the air (Witing et al., 2018). The application of biofertilisers seems to build up nutrient content in the soil, as they are released more slowly than mineral fertilisers (Ju et al., 2018). Biofertilisers also have less odor than manure when applied as fertiliser (Crolla et al., 2013), In some cases, the digestate from anaerobic digestion can be toxic due to zinc, copper or cadmium concentrations, and it requires transportation over long distances (Surendra et al., 2015). There is also a eutrophication issue which is in common for all fertilisers, as it often depends on timing for application, soil characteristics, $\mathrm{pH}$, and if the fertiliser is mixed into the soil (Crolla et al., 2013). Eutrophication and acidification can be problematic in digestate management due to the conversion of nitrous nutrient to $\mathrm{NH}_{3}$ and potential run-offs, but this can often be managed by improving digestate storage and application methods (Vaneeckhaute et al., 2018). Recirculating nutrients can be 
done in several ways; process-based treatments are composting or anaerobic digestion. Composting is done in an aerated environment and does not recover energy from the process, and the final product is more used as a soil conditioner than fertiliser (Haug, 2018). Biogas solutions, on the other hand, contribute with both fertilising and soil conditioning effects.

Biogas solutions can be used as a pre-treatment for lignocellulosic materials, as they can break down hemicellulose and expose chemical building blocks which can be used for further processing (Surendra et al., 2015). Anaerobic treatment of organic materials can be used on waste water streams and reduce the contents of, for example, chemical oxygen demand (COD) and volatile fatty acids (VFA) (Costa et al., 2013). The flexibility of anaerobic digestion is often what makes it strong in comparison to other alternatives. Anaerobic digestion is a treatment which can handle wet substrates without becoming too energy intensive (Mountraki et al., 2016). These examples may imply the relevance of biogas solutions in biorefineries or other bio-based industrial systems.

Historically, the research focus of biogas solutions has changed. The early research from the 70s and 80s focuses on biogas solutions (anaerobic digestion) as waste or waste water treatment solutions (see Rantala and Väänänen, 1985; Schmidell et al., 1986); Haberl et al., 1991). During the 90s, a large focus of the research was on technology and the digestion phase (see Angelidaki and Ahring, 1992; Li and Noike, 1992; Hansen et al., 1998), while the research after 2000 connects biogas solutions to environmental and sustainable solutions (see Murphy et al., 2004; Möller and Müller, 2012; Crolla et al., 2013; Daroch et al., 2013; Olsson and Fallde, 2015). Lately, there has been an increase in researching circular systems and the fertilising abilities of the digestate. At the same time, knowledge about fertilising abilities are becoming more widespread ( Kouřimská et al., 2012; Barbosa et al., 2014; Wentzel and Joergensen, 2016; Risberg et al., 2017). This development is probably mirroring the development in society, but the question remains of if methods for assessing the new challenges are on the way.

\subsection{Overlaps between the research fields}

A literature overview was performed in October 2018 using the database Scopus. The search terms used for each research area were (biogas OR "anaerobic digestion"), (biorefinery OR "bio refinery" and (sustainability AND "system analysis"). The search results in parentheses in Figure 2 refer to a search performed using "system analysis", without the sustainability term, in combination with the other search terms. The search was restricted to search terms matching title, keywords, author and abstract. The majority of the results were journal articles, but conference papers, book chapters and reviews also show up in the results. There were no time limits applied, but the number of articles increased rapidly after the year 2000 in all of the research fields. The results will depend on what search terms are used, 
but still, the results of this Scopus search indicate that, although fairly large research areas, the overlaps between the research areas are small.

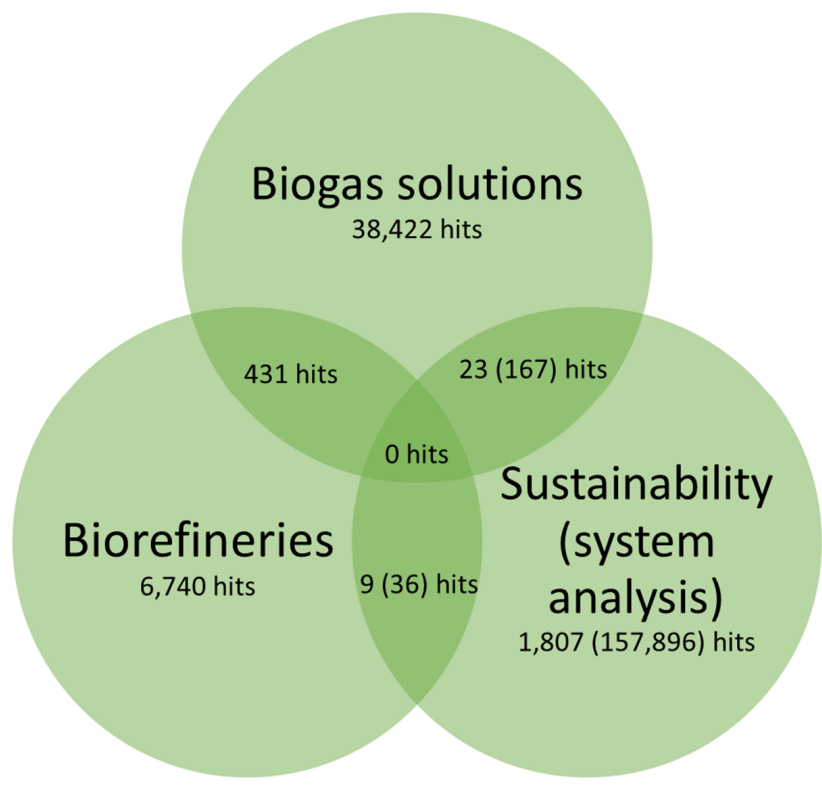

Figure 2. Scopus search for overlaps between research areas. The number of hits is presented for each research area and the overlaps. In parentheses are the results when "system analysis" replace "sustainability system analysis" as a search term.

\subsubsection{Biogas solutions in biorefinery research}

Biogas solutions in biorefinery research are often examples of add-on solutions, where anaerobic treatment is mentioned as a way of generating energy or treating waste water, for example (Joelsson et al., 2015). Others assess biorefineries where the core technology is anaerobic digestion (see Surendra et al., 2015; Sawatdeenarunat et al., 2016). Some research even mentions that biorefineries contribute more to the circular bioeconomy by applying biogas solutions (Pérez-Camacho and Curry, 2017). In the biorefinery concept, where the aim is to improve value from biomass and even upcycling by-products to a higher value, biogas solutions may increase profitability (Langeveld et al., 2012; Martin and Parsapour, 2012). Studies focusing on integrated biogas solutions in biorefineries have discovered that biogas solutions are suitable as a final treatment in microalgae-based biorefineries (Mussgnug et al., 2010). Others identified the potential of internal energy generation for the biorefinery (Bravo-Fritz et al., 2016). There are studies of biogas solutions in biorefineries, but it is still rare to look at development potential or impact due to biogas solutions integrated in biorefineries. 


\subsubsection{Sustainability system analysis in biorefinery research}

Sustainability system analysis in biorefinery research boils down to the importance of broad methods when evaluating biorefineries requiring methods such as LCA or MCA. It is often LCA that is used for sustainability system analysis of biorefineries (see Ahlgren et al., 2015; Gullón et al., 2018). The Scopus search in Figure 2 showed few results where system analysis and biorefineries are combined, but this can be, for example, a limiting factor in the search terms. If LCA and biorefineries were searched for together, the results might improve. There is research trying to improve sustainability assessments in bio-based industrial systems, that has resulted in recommendations for biorefineries applying LCA on their processes (Ahlgren et al., 2015). For example, the LCA should include assessments of biodiversity, soil degradation and water use. Keller et al. (2015) try to broaden the scope of biorefinery assessments through developing an ILCSA which includes feasibility aspects connected to risks, technologies and infrastructure. A review by Parajuli et al. (2015) considers several sustainability assessment methods on biorefineries and concludes that MCA is a suitable method that has a wide perspective, but also that value-based methods and out-ranking methods can be useful. They also emphasise the importance of assessing the sustainability of the biomass supply.

\subsubsection{Sustainability system analysis in biogas research}

Sustainability analysis of biogas solutions has been performed in several cases, and some examples come from biogas solutions in industrial and agricultural systems. Feiz and Ammenberg (2017) developed an MCA method for assessing feedstock which can be used in biogas plants. They try to identify what factors are crucial for the feasibility, risk avoidance and performance of different substrates, while other studies aim at evaluating environmental impact from biogas solutions (see Börjesson and Berglund, 2006, 2007). Feiz and Ammenberg (2017) conclude that biogas solutions can lead to both direct and indirect benefits and that methods for assessing biogas solutions require special attention as a result of the complexity of biogas solutions. It is interesting to understand how the historical development of biogas solutions calls for new methods. In the beginning, the focus was on techno-economic assessments; then, when environmental issues became more important, the life cycle assessments became important while the circular systems assessed required broader tools which include a wider sustainability concept.

\subsection{Research gaps}

The main gaps identified in the relevant research areas are connected to the overlaps of the different research fields. Figure 2 indicates this, but the gaps are mainly identified through reading scientific literature from the different fields and trying to find assessments which cover the connections between biogas solutions and biorefineries. As biogas solutions can treat bulky organic materials, the application 
of the technology was thought to be more common in biorefineries. It is also rare to see comparative assessments of by-product valorisation methods.

For example, sustainability assessments of biogas solutions and biorefineries applying a broad take on external effects are lacking, which can be noted in Subsection 2.4.2 and 2.4.3. If including effects on other actors such as farmers, municipalities and customers, the influence from biogas solutions and biorefineries becomes much wider than the common evaluation of environmental impact or techno-economic feasibility from biogas solutions and biorefineries.

When it comes to the combination of biogas and biorefinery research, the gap is large regarding biogas solutions' impact on the system, and the role of biogas solutions in biorefineries could be better identified according to Subsection 2.4.1.

There is a gap overlapping all three research fields when it comes to the assessments of biogas solutions in biorefineries. A few existing assessments focus on one aspect of the biogas solution, either the waste treatment method or the use of biogas for energy, but it can be interesting to study the role which biogas solutions have for the sustainability of a biorefinery and its development potential. Broader assessments need to be done and the connection between the biogas solution's impact on a biorefinery and surroundings should be evaluated.

This research aims at generating information to the biogas and biorefinery field about the enhanced performance and role of biogas solutions. It should also contribute to broader assessments in these fields while connecting the development of biogas solutions in biorefineries to the circular bioeconomy. 
HOW DO BIOGAS SOLUTIONS INFLUENCE THE SUSTAINABILITY OF BIO-BASED INDUSTRIAL SYSTEMS? 


\section{METHODOLOGY}

This chapter introduces the method used for creating this thesis. The method is mainly based on an analysis of the three appended articles. The methods used to perform the research are described within each article, but a summary of the articles and methods are presented in a table. An analysis method used for the appended articles is also described. Lastly, a section regarding the author's research journey is included to easier understand this work. 


\subsection{Research design}

This section presents the method that was used in the author's research that supports this thesis. The main input to this thesis is the results from the three appended papers, which are summarised in Table 1 . They are assessed by extracting information relevant to the research questions, as illustrated in Figure 3. The analysis method describes in greater detail how the information from the articles has been gathered. Results, discussion and conclusions in the different articles are examined in connection to other literature related to the aim of this thesis. The actual process includes going through each article appended with the research questions of the thesis as a new layer to retrieve information. This new knowledge is summarised in Chapter 4, while Chapter 5 tries to connect the ideas from the results to the scientific literature. 
Table 1. Summary of Articles I, II and III, where the background, aim, system boundaries, methods, results and conclusions are presented.

\begin{tabular}{|c|c|c|c|}
\hline & Article I & Article II & Article III \\
\hline Background & $\begin{array}{l}\text { Biogas solutions can treat a } \\
\text { variety of organic materials } \\
\text { Agricultural, forest and } \\
\text { aquatic sectors are interest- } \\
\text { ing biomass sources } \\
\text { - Biogas solutions have been } \\
\text { applied to all three of these } \\
\text { sectors }\end{array}$ & $\begin{array}{l}\text { Several alternatives for } \\
\text { treating stillage, a by-prod- } \\
\text { uct from ethanol production } \\
\text { - Impact on biorefinery sus- } \\
\text { tainability from the different } \\
\text { by-product valorisation al- } \\
\text { ternatives }\end{array}$ & $\begin{array}{l}\text { Weaknesses in assessments } \\
\text { of biorefineries } \\
\text { Broad assessments are } \\
\text { needed }\end{array}$ \\
\hline Aim & $\begin{array}{l}\text { Characterise biogas solu- } \\
\text { tions in bio-based industrial } \\
\text { systems and identify their } \\
\text { contributions to sustainabil- } \\
\text { ity } \\
\text { - Find the impact on the } \\
\text { growth and development of } \\
\text { bio-based industrial systems }\end{array}$ & $\begin{array}{l}\text { Analyse and understand } \\
\text { how different treatments of } \\
\text { low-value by-products affect } \\
\text { the economic and environ- } \\
\text { mental performance of a bi- } \\
\text { orefinery }\end{array}$ & $\begin{array}{l}\text { Develop a method and show } \\
\text { how it can be operational- } \\
\text { ised by applying it to a bio- } \\
\text { refinery } \\
\text { - Contribution of such ap- } \\
\text { proach to more comprehen- } \\
\text { sive assessments of biorefin- } \\
\text { eries }\end{array}$ \\
\hline $\begin{array}{l}\text { System } \\
\text { boundaries }\end{array}$ & $\begin{array}{l}\text { Direct impacts from the as- } \\
\text { sessed bio-based industrial } \\
\text { systems are in focus } \\
\text { Indirect effects on society } \\
\text { and environment have been } \\
\text { discussed }\end{array}$ & $\begin{array}{l}\text { Direct impacts from the by- } \\
\text { product valorisation alterna- } \\
\text { tives are included } \\
\text { - Indirect effects from the by- } \\
\text { product valorisation alterna- } \\
\text { tives have been mentioned in } \\
\text { the discussion }\end{array}$ & $\begin{array}{l}\text { Direct impact from the } \\
\text { whole biorefinery network } \\
\text { is assessed } \\
\text { - Indirect impacts from the bi- } \\
\text { orefinery network are incor- } \\
\text { porated in the assessment }\end{array}$ \\
\hline Method & $\begin{array}{l}\text { Choose case studies on agri- } \\
\text { culture, forest and aquatic } \\
\text { bio-based industrial systems } \\
\text { - Literature review on each } \\
\text { type of bio-based industrial } \\
\text { system above } \\
\text { - Interviews with case study } \\
\text { representatives }\end{array}$ & $\begin{array}{ll}\text { - } & \text { Scenario creation } \\
\text { - } & \text { LCA for climate impact } \\
\text { - } & \text { Nutrient recirculation as- } \\
\text { sessment } \\
\text { - Energy Input/Output assess- } \\
\text { ment. } \\
\text { - Interviews and study visits }\end{array}$ & $\begin{array}{ll}\text { - } & \begin{array}{l}\text { Developing a specific MCA } \\
\text { framework for biorefineries }\end{array} \\
\text { - Interviews or workshops } \\
\text { with several actors for data } \\
\text { collection } \\
\text { - Calculations for quantitative } \\
\text { indicators }\end{array}$ \\
\hline Results & $\begin{array}{l}\text { Relevance of biogas solu- } \\
\text { tions in bio-based industrial } \\
\text { systems } \\
\text { Each sector has several } \\
\text { added-values identified: } \\
\text { - reduced costs } \\
\text { - greener image } \\
\text { - solve energy } \\
\text { problems } \\
\text { - solve waste } \\
\text { problems }\end{array}$ & $\begin{array}{l}\text { Six development scenarios: } \\
\text { - fodder } \\
\text { - fertiliser } \\
\text { - incineration } \\
\text { - produce fuel at a local bio- } \\
\text { gas plant } \\
\text { - produce fuel at a distant } \\
\text { plant } \\
\text { - heat and power at local bi- } \\
\text { ogas plant } \\
\text { Local biogas for vehicle fuel } \\
\text { and fodder receives the best } \\
\text { results financially and envi- } \\
\text { ronmentally }\end{array}$ & $\begin{array}{l}\text { The results indicate fodder } \\
\text { or biogas solutions to be } \\
\text { feasible, well-performing } \\
\text { and least risky alternatives } \\
\text { The method identifies which } \\
\text { aspects are important for } \\
\text { evaluating development po- } \\
\text { tential }\end{array}$ \\
\hline Conclusions & $\begin{array}{l}\text { Biogas solutions can be im- } \\
\text { portant for upcycling } \\
\text { Biogas solutions may enable } \\
\text { development and are useful } \\
\text { during transitions }\end{array}$ & $\begin{array}{l}\text { Good results for upcycling } \\
\text { poor by-product streams } \\
\text { through biogas solutions } \\
\text { Scenario design can be im- } \\
\text { portant for the results }\end{array}$ & $\begin{array}{l}\text { Include feasibility indicators } \\
\text { to provide better support for } \\
\text { decision-makers } \\
\text { - Involve stakeholders to } \\
\text { broaden the perspectives }\end{array}$ \\
\hline
\end{tabular}


The articles have slightly different purposes, which give them a certain position in this thesis. The contributions to the research questions are shown in Figure 3.

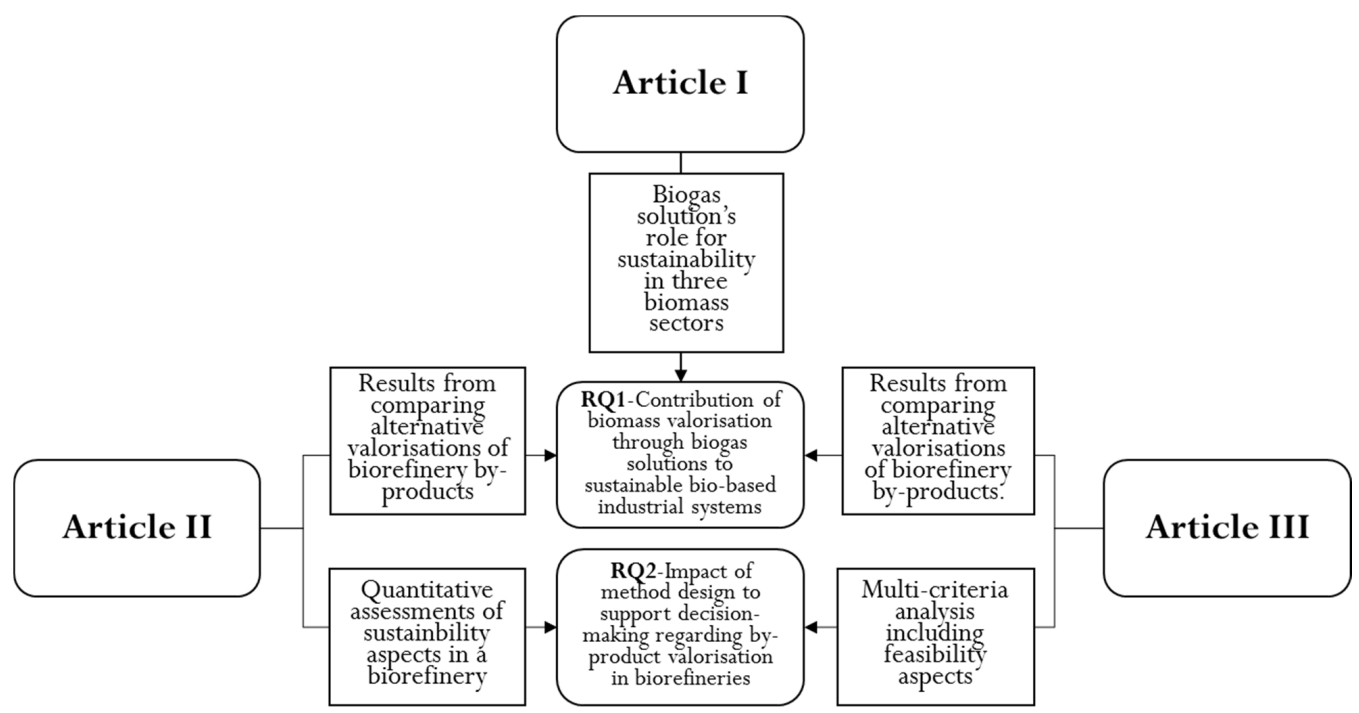

Figure 3. Illustration of each article's contributions to the research questions.

Article I provides an overarching picture of the three major biomass sectors, agriculture, forestry and aquaculture, where biogas solutions are relevant. Articles II and III go more in-depth into one case and then use different methods for assessing it. The case studied in Articles II and III belong to one of the common trades, agriculture, and can be seen as a biorefinery producing ethanol, starch, gluten, animal feed, biomethane and biofertiliser from wheat and process by-products. The case was chosen due to alternative valorisation methods already in place today for the by-product stillage, leading to facilitated data collection as the assessment is to compare six different valorisation alternatives of stillage. The case is situated in the middle of Sweden to enable study visits and interviews. Article II applies several different quantitative methods to achieve the results due to the aspects evaluated: greenhouse gas emissions, energy balance, nutrient recirculation and finances. A life cycle assessment was performed for $\mathrm{kg} \mathrm{CO}_{2}$ emissions per tonne of stillage treated. The energy balance estimated energy need in the processes, and generation of energy per tonne of stillage treated. Regarding nutrient recirculation, a method was designed to show to what extent biofertilisers could replace mineral fertilisers. The nutrient content of the biofertiliser was compared to the amount of nutrients required to grow the wheat used in the biorefinery. The financial assessment mainly focused on the potential income for the biorefinery depending on different valorisation alternatives. More detailed information can be found in Article II. In Article III, a multi-criteria tool was developed to cover more contextual aspects related to feasibility, performance and risk for different valorisation alternatives. This method is described in detail in Feiz and Hagman (report to be published) and is introduced in Article III. The idea with a multi-criteria assessment 
was to complete the quantitative assessment and cover aspects which require more qualitative approaches. The data collected for quantitative assessments originate to a large extent from the biorefinery assessed and the collaborating biogas plant.

\subsection{Analysis method}

The results of this thesis focus on a few main topics revealed through the results of Articles I, II and III. Figure 4 illustrates the pathway for the analysis method. In practise, the first step was to identify topics in the results and discussion chapters from Articles I, II and III. When identifying the topics, certain criteria were used. The topic should connect to the sustainability of biogas solutions in bio-based industrial systems or respond to methodological issues with sustainability assessments of bio-based industrial systems. The topics should be discussed in the articles and contribute with information which has not been widely discussed earlier. All topics identified were then analysed and merged into suitable main topics, based on possible subject overlaps, which could be used as subsections. These are presented in Chapter 4 and illustrated in Figure 5. The topics were then the foundation for the analysis results of the appended articles.
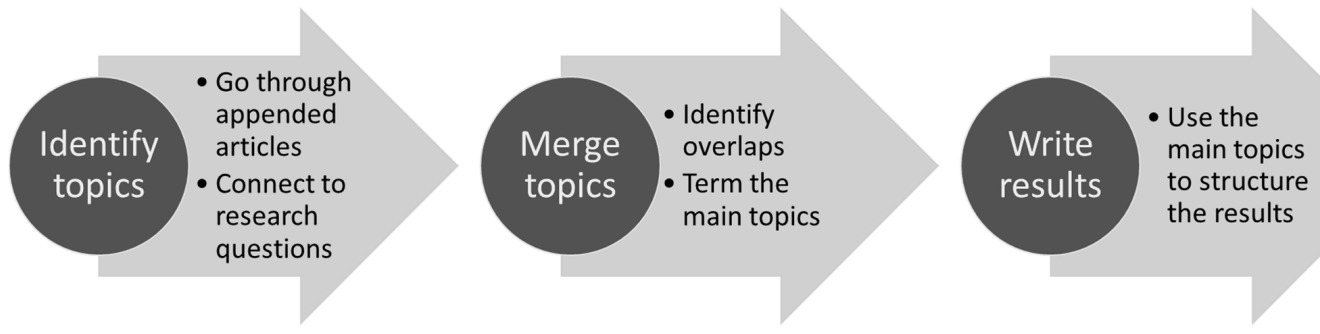

Figure 4. Illustration of the method for choosing the analysis topics.

\subsection{Reflection upon research journey}

The research for this thesis started out in the summer of 2015. Projects within the Biogas Research Center (BRC) were initiated, and the case of a wheat biorefinery was studied within Research Package 3: "Quantitative systems analysis towards improved resource efficiency of biogas solutions - Critical factors and uncertainty management" and Research Package 2: "Strategic multi-criteria analysis of biogas solutions - From assessment of substrate to other perspectives". These two projects influence the selection of methods used for the case study in Articles I and II. How the case was chosen is influenced by involved business partners from BRC, as well as the scenarios where treatment of the by-product was done either through biogas 
solutions or other alternatives. While gathering data from the studied case the specific MCA method was developed together with Roozbeh Feiz. In spring 2016, a special issue from the Journal of Cleaner Production focused on the bioeconomy, and Article I was written for this purpose. The idea was that the article could provide an overview of biogas applications in the biorefinery field. During the same time, a report regarding scientific literature for biogas benefits was written for $\mathrm{Bi}$ ogas Öst (Hagman and Eklund, 2016). The report was not planned but has contributed with a large literature review and an interesting analysis connecting biogas impacts with the UN development goals. As soon as the results for the quantitative and qualitative assessments started to take form, Articles II and III were written. Article II was sent to Waste and Biomass Valorization as it seemed to fit the topic well. The third article can possibly be sent to Integrated Environmental Assessment and Management or Biomass and Bioenergy. 


\section{RESULTS}

This chapter presents the results, connected to the research questions, through the analysis of the appended articles. The results are structured according to the topics found through the analysis method, which are connected to the research questions. 
The results will be presented in the structure identified through the analysis method. The results from the analysis method are illustrated in Figure 5. As results from Article I may originate from literature studies, some of the topics are not original from this author but have been synthesised in Article I.

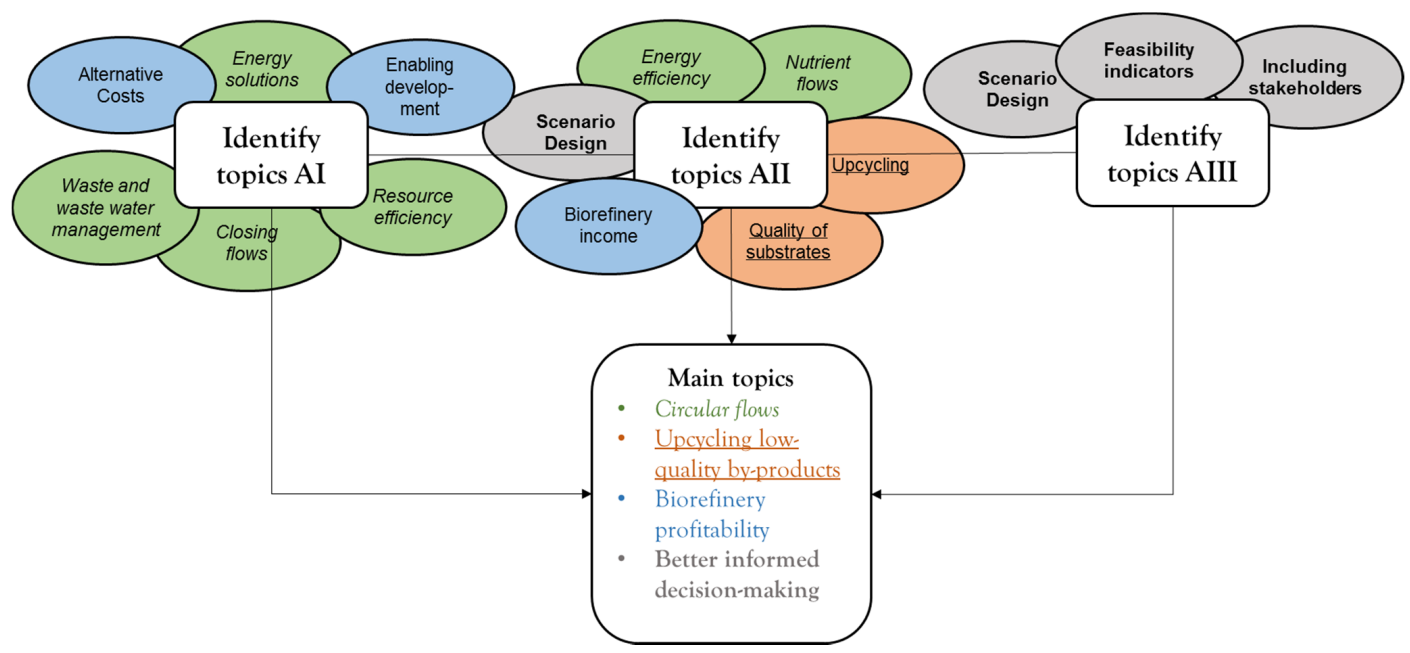

Figure 5. Different topics identified from the result and discussion chapters in the appended articles.

Specific topics have emerged from an analysis of the three appended articles. Several of the topics raised in the articles refer to resource efficiency, nutrient flows, energy solutions and waste management. These connect in some way to the ability to create circular flows in bio-based industrial systems. This topic is further separated into resource management, energy and transportation, and nutrients. The concept of upcycling of lower quality by-product streams through biogas solutions is raised mainly in Article II. It is related to circular flows, but as the conclusion is not found in other literature, it here receives its own section. Some topics relate to economic or financial aspects of biogas solutions in bio-based industrial systems. Therefore, results regarding the profitability are included as they connect to the sustainability of the bio-based industrial system. The last section is termed "betterinformed decision-making", as the articles have identified some aspects important to include in strategic assessments of bio-based industrial systems.

\subsection{Circular flows}

An introduction to this section can be made by demonstrating the case of the aquatic biorefinery studied in Article I. Its plan is to implement a circular system where industrial waste from fish processing is digested in a biogas plant, and the nutrient-rich digestate will be used in algae farms where the algae is used for extracting high-value products, such as proteins, lipids and chemicals, while the byproducts of these processes return to the biogas digesters as well. Regarding the 
energy use, the raw gas produced will generate heat for the algae farm and electricity for cooling the food products of the fish processing industry. This example shows the potential resource efficiency from biogas solutions in bio-based industrial systems that can improve sustainability.

\subsubsection{Resources and waste water}

Using resources efficiently results in more products of higher value being produced, with less impact. There is an opportunity for reducing the amount of waste and waste water in the system through creating circular flows. Resource efficiency can improve competitiveness, according to Article I, mainly since resource-efficient solutions give the bio-based industrial system a better image and brand. Such development may lead to market expansions that could have long-term effects. Biogas solutions provide an opportunity for reusing flows earlier treated as waste or waste water for generating new products. Circular flows cannot be fully achieved, but there is great potential for becoming more resource efficient.

If biogas solutions are providing the bio-based industrial system with waste water treatment, the need for energy, chemicals or additives can be reduced compared to other purifying methods (Article I). This is because biogas solutions are based on natural digestion processes that occur under anaerobic conditions. Inside the digestion chambers, chemical oxygen demand (COD) and biochemical oxygen demand (BOD) concentrations are reduced through anaerobic digestion by microorganisms. This means that bio-based industries that discharge their waste water into rivers or seas will improve water quality through biogas solutions (Article I). Emissions from any process industry that influences water quality is often strictly regulated. When comparing anaerobic and aerobic treatments of waste water, the literature review in Article I identified some conditions when anaerobic treatments can be superior to aerobic treatments of waste water. These are if the gas generated is used internally, the temperature of the substrate is high, there is a lack of space for aeration, or when the soils are not suited for aerobic treatment. Having waste water treatment which generates energy and nutrients that can be used internally or be sold improves the sustainability of bio-based industrial systems.

\subsubsection{Energy and transportation}

Energy efficiency and transportation are two areas relevant for energy management of bio-based industrial systems. Using the produced gas internally can replace natural gas in their processes, generate electricity and heat or be used for fuel for transportation to the bio-based industrial system. When comparing different uses of raw gas, there are various pathways optimal for different bio-based industrial systems. In Article II, a local biogas plant producing vehicle fuel is better in regard to energy efficiency compared to a local biogas plant producing heat and power and a distant biogas plant. The way the biogas is used differs substantially between different cases. In the forest and aquatic cases in Article I, actors prefer using heat and power to use within their networks, while the actors in the agricultural case produce biogas for vehicle fuel. When assessing energy balance with an 
input/output method as in Article II, the results show that biogas production for vehicle fuel requires the most energy input, as the upgrading techniques are energy demanding. The biogas scenario generating heat and power only requires some energy for heating and mixing. Regarding the energy generated, biogas for heat and power has a lower quantity and quality compared to the fuel produced from biogas solutions. Worth noticing is that conversion losses which occur in the generator will occur when the fuel is used in an engine as well. Biogas solutions can contribute to a bio-based industrial system by improving energy efficiency and possibly reducing energy need from unsustainable sources.

If biogas is used as vehicle fuel in a bio-based industrial system, the climate impact can be reduced, as transportation is often a problem for bio-based industrial systems. Production sites are often situated where biomass is produced, but far from markets, and transportation is noted as a challenge in all three appended articles. Through the establishment of biogas solutions, transportation of substrates is potentially reduced. This was an important argument for implementing a biogas production facility in the aquatic case (Article I) since the existing waste flows were transported to distant biogas plants. Articles II and III indicate similar results with an advantage for local biogas plants compared to distant ones. If reducing transportation through biogas solutions, energy use, climate impact and costs can be reduced.

\subsubsection{Nutrients}

Nutrient recirculation means that phosphorus $(\mathrm{P})$, nitrogen $(\mathrm{N})$ and other nutrients that are available in organic wastes are reused as fertiliser for crops. As the need for nutrients becomes more urgent, the research supporting the closing of nutrient flows becomes more important. Articles I, II and III highlight the importance of the biogas solution's contribution to nutrient recirculation. Article I identifies the advantages of nutrient recirculation in bio-based industrial systems through literature and case studies. Most of the literature does not assess the level of nutrient recirculation or evaluate methods for bio-based industrial systems to improve nutrient recirculation. Typically, the role of biofertiliser is not discussed in articles about biogas solutions in bio-based industrial systems at all, possibly because the application of biofertiliser is not practised. The values from the biofertiliser can both be internal for the bio-based industrial systems contributing with income from a new product and external where the share of organic farming in a region is increased. There are examples (Article I) where nutrients from anaerobic digestion are used in algae farms, or where the biofertiliser decreases mineral fertiliser use. Depending on the quality of the biofertiliser, several kinds of fertilisers can be substituted. In bio-based industrial systems, mainly pure and well-defined organic materials are digested, and therefore the biofertiliser from them have higher quality than biofertilisers from co-digestion plants involving household food waste. A potential problem is if there are additives in earlier processes that are harmful to the biofertiliser (Article I). In the studied Swedish context, owners of biogas plants 
strive to achieve a high-value biofertiliser. It can even be certified for organic farming (Article III). This is the reason that organic farming can increase in regions surrounding biogas plants (Articles II, III). Biofertilisers can be applicable in several settings and have easily accessible nutrients that can replace mineral fertiliser.

In all of the articles, nutrient recirculation is captured in different ways. In the quantitative assessment of Article II, the nutrient content of the biofertiliser is compared to the amount of nutrients required to grow the wheat which was used in the biorefinery. The results show that $35 \%$ of the $\mathrm{P}$ required to produce the original raw material (wheat) is covered by the $\mathrm{P}$ content in the biofertiliser. The corresponding amount for ammonium (NH4) is $17 \%$. Such ratios have not been found in the literature, making it hard to know how to evaluate the degree of nutrient recirculation in biorefineries in general. In the MCA (Article III), nutrient recirculation is instead based on how much of the available materials are recirculated for use as nutrients. The biogas scenarios all use digestate as biofertiliser and score very well in this aspect. In contrast, the incineration scenario is assumed to have no nutrient recirculation, since $\mathrm{P}$ recovery from bottom ashes does not occur.

The results from the articles show that nutrient recirculation should be regarded as a significant measure for improving the sustainability of a system. There is a need for a more standardised way of measuring the degree of nutrient recirculation which also includes other aspects of biofertilisers such as an increased amount of micronutrients, microorganisms and carbon content in the soil as well as a more resilient soil environment that can resist changes such as drought or weeds. A drawback with biofertilisers identified in Article III, which needs to be assessed, is the risk of potential eutrophication when applied.

\subsection{Upcycling low-value by-products}

By-product flows typically loose interesting qualities when cascaded in a biobased industrial system. This depends on if high-valued fractions of biomass are extracted earlier in the processes. The suitability of different treatment alternatives for waste and waste water also influence the quality of the by-product flows in regard to energy, protein or nutrient content, and are therefore relevant to investigate. The cascading of biomass is sometimes illustrated as a pyramid, where higher-valued products are extracted in small volumes, leaving lower-value biomass for the next level of processing. In Article I, a modified picture of the ecopyramid is provided (Figure 6) which also includes upcycling in distinction from cascading. The idea is that bio-based industrial system strategies shall not only strive for high-value product extraction and always receive low-value by-products; they shall also consider the opportunity for upcycling low-value materials into high-value products. 


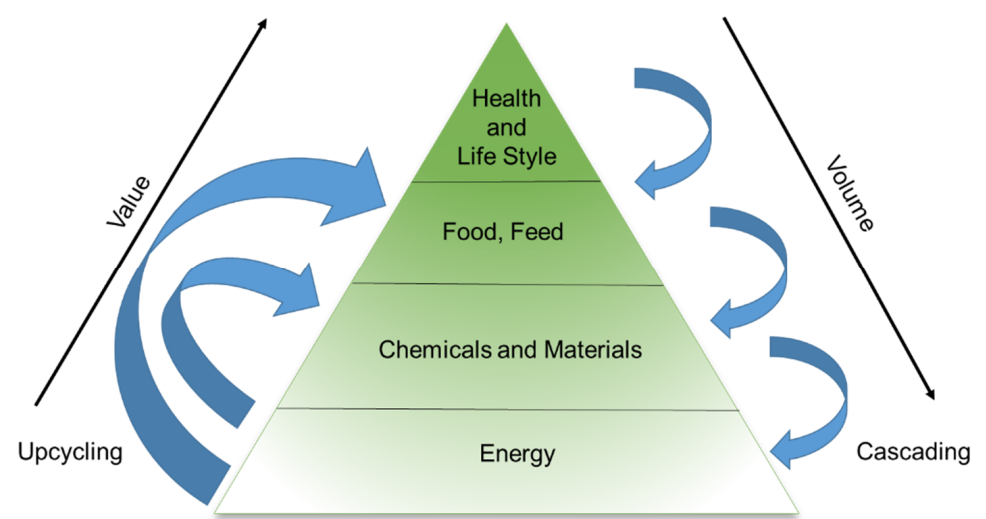

Figure 6. Modified version of the Eco-pyramid, including upcycling possibilities as a complement to cascading. Presented in Hagman et al. 2018 (Article I).

In Articles II and III, the studied case is a biorefinery producing ethanol as its main product and has lower quality by-products compared to other ethanol plants due to its extraction of gluten, which is rich in proteins. The gluten extraction lowers the protein content of the biomass in the assessed case, making it lower than in similar cases. The remaining biomass, the stillage in the studied case, has about $17 \%$ protein content per kg Dry Matter (DM), while other studies have reported that protein content can range up to $41 \%$ protein per $\mathrm{kg}$ DM in stillage produced from pure ethanol plants. In Article II, the sensitivity analysis set out to assess how this difference in protein content affected the results regarding GHG emissions for production scenarios of fodder and local biogas production for fuel. System expansion of the LCA shows that when a high protein stillage replaces fodder, the avoided net GHG emissions increase from 53 to $138 \mathrm{~kg} \mathrm{CO}_{2}$-eq/tonne of stillage. Corresponding results for the local biogas as fuel production are increased from 57 to $80 \mathrm{~kg} \mathrm{CO}_{2} /$ tonne of stillage. The financial outcome of the fodder scenario also benefits from higher protein content as well. The difference in emissions for the biogas scenario is mainly based on changes in the nutrient composition. The conclusion of this sensitivity analysis for GHG emissions is that stillage high in protein content should be used for fodder, while biogas solutions are still a competitive option for stillage with low protein content.

Further case studies including different protein levels of stillage would provide a richer picture, as well as combining the fodder scenarios with digestion of the manure from the animals. The ability of the biogas processes to digest protein varies and is also a factor to take into account in further studies. In any event, the methods evaluating biorefineries need to include qualitative aspects in some way for comparability and relevance between different facilities. 


\subsection{Biorefinery profitability}

Sustainable biorefineries need to be economically sustainable. Several financial advantages are identified for biorefineries, and these can be related to either increased income or reduced costs. Increased income can connect to new products for sale in the bio-based industrial system's product portfolio. Both biogas and biofertiliser have the potential of bringing in money, especially if further valorised. There are examples of biogas solutions solving bottlenecks in by-product handling or waste management (Article I), leading to increased overall production in the bio-based industrial system due to biogas solutions.

Decreased costs can be related to less transport required, either when former waste treatments were performed externally or when lower volumes have to be handled after anaerobic treatment of sludge or wastes (Article I). The cost reduction of replacing external or former internal waste management systems with biogas solutions can influence decision-making in bio-based industrial systems. If biogas solutions are used for internal energy use, there is a possibility to reduce costs. Increased costs are mainly connected to implementation and operation costs for the biogas solutions (Article I). There are also costs related to disturbances in production when the biogas solution has problems (Article I).

The results from the economic assessments in Articles II and III mainly focus on financial data. Article II focuses on direct costs and income for the biorefinery in the different development scenarios. The results in Figure 7 are normalised, where the sale price of the substrate (income for the biorefinery) is set to 1 in the localbiogas-for-fuel scenario. This was done to protect the involved actors. Costs are mainly connected to transport of stillage from the biorefinery. Incineration of stillage is a costly solution for the biorefinery, while most other actors handling stillage are willing to pay for it. The net results weigh together costs and income, which results in fodder and local-biogas-for-fuel scenarios having the best financial results. If transport for the fodder scenario was shorter or cheaper, the income for the biorefinery could increase as the costs are reduced. 


\section{Financial results}

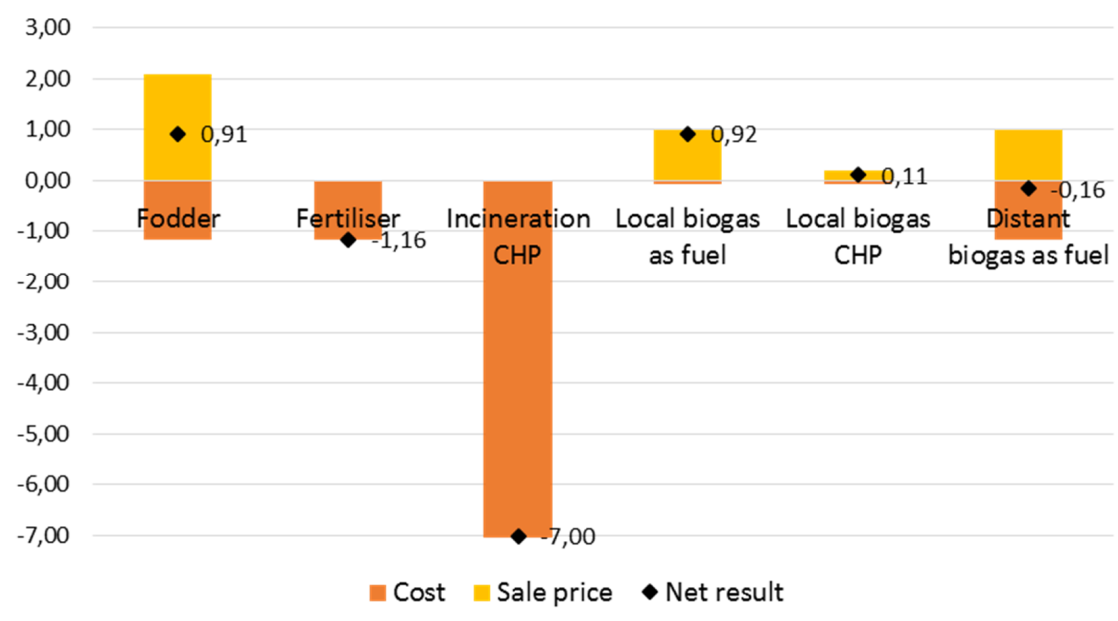

Figure 7. Financial results of Article II, normalised to illustrate the relation between the scenarios (Hagman et al., submitted 2018). Fodder and local biogas as fuel provide the same net income to the biorefinery. Incineration is the most costly alternative.

Economic evaluations for biogas solutions in bio-based industrial systems could be improved if the assessments would include the financial benefits of expansions of the existing production system, improvements in processes or waste and waste water treatments, and better estimates of alternative costs (Article I). Alternative costs are costs related to activities that the bio-based industrial system needs with or without biogas solutions. This could be external energy consumption or cost for other waste management alternatives. If this is shown in assessments evaluating biogas solutions in bio-based industrial systems, the overall performance of the system would become more relevant. The value of improved resource efficiency is rarely evaluated, but it can contribute to profitability by producing more products to sell.

\subsection{Better-informed decision-making}

To achieve better-informed decision-making, the methods applied to different cases need to provide results which can easily be interpreted and include a range of aspects relevant for future development. The challenges with broad sustainability assessments of bio-based industrial systems are related to the variety of products produced in the facility, how the system boundaries shall be defined and what aspects should be included in the assessment. These challenges have been identified in the literature but also become clear when working with Articles I and II. In Article II, the development scenarios assessed were based on the upcycling of the by-product stillage in different respects. In this way, we limited the challenge of assessing several material flows at once and could focus on the other challenges. 
Deciding on what aspects should be evaluated was still complicated. In the quantitative assessment of Article II, the focus was on the potential in four different areas: GHG emissions, energy balance, economy, and nutrient recirculation. The main thing added compared to other studies is the estimation of nutrient recirculation. To include aspects related to the feasibility of certain development scenarios more qualitative aspects were needed. This led up to a multi-criteria assessment, MCA (Article III). The MCA includes feasibility and risk-related aspects such as infrastructural readiness, technological readiness, geographical and physical suitability, actor's readiness, planning horizon and business model, institutional support, public acceptance, long-term risk avoidance, and control of supply chains and markets of the development scenarios. Feasibility indicators can inform decisionmakers if there is a practical problem with a specific development scenario and therefore rule it out before making more extensive assessments.

After performing the assessments in Articles II and III, there were still indicators identified as relevant to include to create better decision support. Indirect effects such as the potential enabling of production expansion, strengthening company image used for marketing, increased value from the biomass, and attractiveness towards customers and potential business partners have not been assessed (Article III). There are cases in Article I where biogas solutions have improved the efficiency of the bio-based industrial systems as a whole and increased product flexibility, but the value of this has not been estimated. Some external effects which have not contributed to the actual results of Article II are that the use of biogas cars in the municipal activities that have led to reduced emissions of particles and GHG emissions in the municipality would not have been possible without the local biogas plant. These solutions are potential enablers for municipalities to reach their environmental goals. Other external effects that could be included are land use, increased demand for biomass and suitability of the feedstock for the purpose (Article III). Some interesting aspects popped up in the assessment of the indicator "local environmental impact" (Article III). Water use, biodiversity, particle release from transports, soil quality due to organic farming and decreased use of fossil fuels were topics that were mentioned during workshops on local environmental impact. They are not quantified, but this shows that external effects may be included in existing indicators of the MCA assessment. There is a risk that actors are not aware of, or forget, aspects that are not explicit in the assessment. A range of indicators can be included in future assessments of bio-based industrial systems, and identifying and deciding which ones are important can be achieved through discussions with relevant stakeholders.

Stakeholders were included in Article III's MCA through workshops and interviews. It is important to include them when assessing development scenarios, as they have a lot of first-hand and fine-grained knowledge and information. The first step is to identify which stakeholders are relevant for the assessment. In Article 
III, the aim was to have one key stakeholder for each development scenario, although fodder and fertiliser alternatives had to be taken care of by the biorefinery's stillage manager. Some information was provided by stakeholders not immediately involved in the actual biorefinery, such as people working for the municipality and biofertiliser customers. They can contribute with different approaches and information regarding external effects which the direct stakeholders might not be aware of, like increased organic farming or improved local air quality due to an increased number of biogas vehicles in town. Stakeholders are also relevant for an economic assessment. An economic assessment could include some kind of business model evaluation (Article I). Biogas solutions can in some ways influence the business model, resulting in economic changes due to new developments which might include new actors in different markets. To succeed with such an evaluation requires interviews with people knowledgeable in the plant operations or strategic decisions. 


\section{DISCUSSION}

This chapter connects the results of the research in the appended articles to the scientific literature and sets out to address the overall research questions of "How can the valorisation of biomass through biogas solutions contribute to sustainable bio-based industrial systems?" and "What is desired in an assessment method to support decision-making regarding by-product valorisation, such as biogas solutions, in bio-based industrial systems?" 


\subsection{The contribution of biogas solutions to sus- tainability in bio-based industrial systems}

\subsubsection{Relevance of biogas solutions in bio-based industrial systems}

Biogas solutions in bio-based industrial systems are relevant as they, to begin with, fulfil three important roles for bio-based industrial systems: they contribute with a nutrient circulation opportunity (Carey et al., 2016); they can contribute to the energy demand of the system (Bravo-Fritz et al., 2016); and, by increasing circular flows, the bio-based industrial systems can become more resource efficient and profitable (Gullón et al., 2018). Biogas solutions are generally proven, well-established technologies (Langeveld et al., 2012). If bio-based industrial systems continue to improve the extraction of high-value products, their need for a solution regarding low-value by-products will become more important. Low-value byproduct streams can have low protein or energy content, or be physically tough to treat. This thesis shows how biogas solutions are useful for generating energy and creating biofertilisers from low-value by-product streams from the bio-based industrial system compared to other treatment alternatives. Gas exchange and quality of the biofertiliser also decrease slightly when components are extracted from the biomass. However, the relative difference is smaller for biogas options than for fodder alternatives. Biogas solutions in bio-based industries have great potential for producing higher-value products from low-value materials (Surendra et al., 2015), and it is more relevant to use those streams for biogas solutions instead of the high-value material flows (Langeveld et al., 2012). Upcycling by-products can increase profit as the quantities handled are large, leading to improved competitiveness and economic benefits (Cesaro and Belgiorno, 2015). This is made possible because biogas solutions are versatile treatment methods which can handle wet or dry substrates with different contents in a cost-efficient way (Ekman and Börjesson, 2011; Mountraki et al., 2016).

Some issues may be challenging in bio-based industrial systems, where biogas solutions can make a difference regarding the chemical use, the sludge treatment in the waste water treatment plant and the on-site energy production system (González-García et al., 2011). In those cases, biogas solutions can potentially reduce sludge volume, lower chemical consumption, and increase operational simplicity, as well as simultaneous energy production and savings when used as a waste water treatment (Thompson et al., 2001). Another benefit identified in the results is how biogas solutions as a waste water treatment reduce COD and BOD content, which means regulatory limitations may be reached (Chan et al., 2009). Biogas solutions can be a way of solving bottlenecks in bio-based industrial systems if the existing treatment systems are not efficient enough (Feiz and Ammenberg, 2017). 
Comparing the functions provided by biogas solutions to other alternatives for treating by-product flows such as fodder, aerobic waste water treatment or incineration illustrate different characteristics of the different treatment methods (Table 2). Biogas solutions contribute to nutrient recirculation, energy generation and waste water management, while the alternatives display different patterns.

Table 2. Alternative treatment methods for biomass evaluated based on nutrient, energy and waste water management.

\begin{tabular}{|c|c|c|c|c|}
\hline & $\begin{array}{l}\text { Biogas solu- } \\
\text { tions }^{\text {a }}\end{array}$ & Fodder $^{b}$ & $\begin{array}{l}\text { Aerobic } \\
\text { treatment }^{\mathrm{a}}\end{array}$ & Incineration $^{c}$ \\
\hline $\begin{array}{l}\text { Nutrient } \\
\text { recirculation }\end{array}$ & Yes & $\begin{array}{l}\text { Yes to ani- } \\
\text { mals }\end{array}$ & $\mathrm{No}$ & $\mathrm{No}$ \\
\hline $\begin{array}{l}\text { Energy } \\
\text { generation }\end{array}$ & Yes & $\begin{array}{l}\text { Yes to ani- } \\
\text { mals }\end{array}$ & No & Yes \\
\hline $\begin{array}{l}\text { Waste water } \\
\text { management }\end{array}$ & Yes & No & Yes & No \\
\hline
\end{tabular}

a) Chan et al., (2009)

b) Lardy and Anderson, (2014)

c) Girotto et al., (2015)

The conclusion from Table 2 is that biogas solutions can contribute in several areas to the bio-based industrial system, which means that combinations of other treatment alternatives might be needed to cover the same effects which biogas solutions provide. The different treatments can be useful for different purposes, and incineration can be more practical for dry biomass (Girotto et al., 2015), while the other three alternatives can use wet flows. When it comes to treating waste water, biogas solutions are better in regard to energy use, nutrient recirculation and sludge reduction, while aerobic solutions remove organic content to a higher degree, have low temperature sensitivity and fewer odour problems (Chan et al., 2009).

Some problems with biogas solutions in bio-based industrial systems seem to be mainly connected to feasibility or economic aspects. The problems seem more dependent on public acceptance, infrastructure and markets rather than direct technological problems. Economically, there are issues regarding the high energy need for substrate mixing in the digesters, and investments can seem too high in relation to the potential return (Bachmann, 2013). If the biogas is being upgraded for fuel, the cost for this can be a barrier (Langeveld et al., 2012). There is a risk for the industry to get locked in with one technology, which could be a problem when better alternatives are developed (Atkinson et al., 2007), and the biogas solutions could disrupt the production facility if there are technical problems (Article I). Most of the other potential problems identified concerning biogas solutions in biobased industrial systems are related either to resource management (Posada and Osseweijer, 2016), which is a problem for any bio-based industrial system, or to 
the products of biogas solutions such as possible methane slippage or eutrophication (Wellinger et al., 2013). All of those direct effects from bio-based industrial systems and biogas solutions can be minimised by taking precautions. Most accidents or problems acknowledged in biogas production are related to human failures (Bachmann, 2013).

\subsubsection{Environmental impact}

Biogas solutions may, among other things, influence environmental sustainability through climate impact, eutrophication and land use issues.

The climate impact is reduced when products from biogas solutions are used for replacing fossil-based products in several different ways, according to the results. Regarding energy generation, the alternative of upgrading raw biogas to biomethane used for transportation or local gas grid seems to have better environmental performance than biogas CHP as long as methane slippages are low (Ravina and Genon, 2015), which was also seen in the results of Article II due to the replacement of fossil fuels. Transportation is a common sustainability challenge for bio-based industries. They are typically situated near raw materials in rural areas (Pereira et al., 2013), resulting in long distances to the market. If transports to the bio-based industrial system normally run on fossil fuels, it means that the use of biomethane for transport would improve the sustainability of the bio-based industrial systems. Biogas as fuel can be used in heavy vehicles, especially if liquefied (Lorenzi and Baptista, 2018). Liquefied biogas takes less than half of the space that usual compressed biogas at 200 bars, but with the same amount of energy. Depending on the energy systems for heat and electricity, there is a potential for improving sustainability if using the biogas for energy generation (Pereira et al., 2013).

Biogas solutions do not only produce energy carriers, as shown in the results. The digestate produced contains an abundance of the accessible nutrients contained in the organic material flows (Crolla et al., 2013). When biofertiliser replaces mineral fertiliser, the climate impact of the bio-based industrial system improves as well (Al Seadi and Lukehurst, 2012). Another way of improving the sustainability of a bio-based industrial system is to increase its production of high-value products and produce competitive bio-based products (Parajuli et al., 2015). Replacing products from fossil sources will improve the evaluated system's sustainability. $\mathrm{CO}_{2}$ emissions from fossil resources add to the net concentration in the atmosphere, while $\mathrm{CO}_{2}$ emissions from bio-based sources are considered as neutral because degradation of biomass will release the same amount which was uptaken during the plant's life. When bio-based industrial systems are assessed, this biogenic $\mathrm{CO}_{2}$ can affect the results if not set as neutral (Ahlgren et al., 2015). 
An environmental issue which is still debated is whether biofertiliser reduces or increases the eutrophication potential when applied to soils compared to other fertilisers. It seems to be the storage of biofertiliser which is the largest risk for eutrophication (Tufvesson et al., 2013). According to Crolla et al. (2013), there are no significant differences between fertiliser alternatives. The eutrophication issue is problematic for all kinds of fertilisers, as it mainly depends on timing for application, soil characteristics, $\mathrm{pH}$, and if the fertiliser is mixed into the soil (Crolla et al., 2013).

The question of land use is mentioned in the results and are important for bio-based industrial systems (Cherubini et al., 2009), as these systems require large amounts of biomass. The feedstock is important since the way it is grown can impact the life cycle impact of the bio-based industrial system (Dressler et al., 2012). Applying biogas solutions to by-product flows may reduce land use (Pereira et al., 2013) because more products can be extracted from the same amount of biomass. Land use is not only connected to the amount of land needed; it is likewise important to take care of the soils which are used by improving their quality in the long term. This is why biofertilisers are important to return to the soil, as they can improve both the carbon content (Witing et al., 2018) and nutrient content (Ju et al., 2018).

\subsubsection{Financial impact}

Financial sustainability relates to profitable bio-based industries through resourceefficient solutions and established markets. Economic assessments of biorefineries identify feedstock as the largest cost for biorefineries, followed by energy costs and transportation among the largest expenses (Höltinger et al., 2014). Energy and transportation costs can be lowered with the introduction of biogas solutions. The results indicate a possibility of reducing costs when implementing biogas solutions as energy generators, but this seems to depend largely on existing energy prices (Langeveld et al., 2012). The results also touch upon resource efficiency through generating more products with the same amount of biomass, which not only reduces climate impact but can potentially improve profitability for a bio-based industrial system as well. Biogas solutions can be operated at fairly low costs and with high flexibility (Langeveld et al., 2012). But there are those claiming the opposite, that there can be challenges regarding optimisation of the facility, costs connected to the mixing in biogas solutions and high investment costs (Bachmann, 2013). Bio-based industrial systems aim at maximising their output while improving the quality of bio-based products and hence improving economic viability (Parajuli et al., 2015). Upcycling by-products or even waste water flows may lead to improved competitiveness (Cesaro and Belgiorno, 2015) and possibilities to enter new markets (Kamali and Khodaparast, 2015). Innovation in bio-based industrial systems can lead to more competitive and secure bioenergy chains (Elghali et al., 2007). The biofertiliser seldom contributes much to financial sustainability, according to this thesis and the scientific literature, as it is rare to get any payment for the biofertiliser even though there is a potential market for it. Specialised actors 
focusing their business on this niche may be more successful, for instance, by including alternative costs in the price and thus add value for being both a soil conditioner and a fertiliser.

\subsubsection{Social impact}

Social sustainability is often connected to environmental and financial sustainability. When a bio-based industrial system is developed, it is often in rural areas (Pereira et al., 2013). This enables employment possibilities, strengthening of the local and regional production systems, and improvement of energy security when biogas solutions are applied to bio-based industrial systems (Posada and Osseweijer, 2016). Social sustainability issues concerning bio-based industrial systems are often connected to food security, biomass availability, land rights, water availability, biodiversity, working conditions, and health and safety impact (Posada and Osseweijer, 2016). The present thesis focuses on Swedish conditions making some of the aspects reported in literature less relevant. However, in Sweden, there are also challenges regarding energy security, rural development and assuring the sustainable use of biomass. It is often regulations and other institutional conditions that are important to assure reasonable social impact by protecting biomass resources and working conditions (Posada and Osseweijer, 2016), where Sweden has been quite successful.

\subsection{Creating assessments for decision support regarding development scenarios in bio-based industrial systems}

There are many assessments of bio-based industrial systems which have a rather narrow scope and focus mainly on environmental and economic assessments of development scenarios.

\subsubsection{Indicators to assess}

The results in this thesis identify several indicators that should be assessed to give better support to decision-makers. Feasibility-related indicators such as policy support, technical feasibility, business implications, public acceptance and regulatory feasibility suggested by (Elghali et al., 2007; Keller et al., 2015) were assessed, although some of the terms were changed in this thesis. Elghali et al. (2007) motivate those indicators as important for involved stakeholders and those planning to develop and invest in bio-based industrial systems. They need to know what potential risks and rewards are available to be willing to develop their ideas. Included in the MCA of Article III were also indicators directly related to bio-based industrial systems: nutrient recirculation and biocascading. Potential changes in the soils due to biofertiliser application (see Björnsson et al., 2013; Prade et al., 2017) can be included in future assessments. Biocascading has been identified as an interesting indicator for bio-based industrial systems by Bergsma et al. (2012), as biomass 
resources are used more efficiently and thus decrease land use issues. Including the indicators mentioned above resulted in a more comprehensive picture of the different development scenarios assessed.

Despite this, even more indicators could be added. As bio-based industrial systems may have a significant impact on the sustainability of biomass resource cultivation and extraction (Dressler et al., 2012), the aspect of land use and indirect land use should perhaps be included (Cherubini et al., 2009). Other environmental issues which could be assessed more often are impacts on water resources, soil degradation, biodiversity and the handling of biogenic carbon (Ahlgren et al., 2015). The environmental assessment can include the potential reduction of environmental impact since bio-based products from bio-based industrial systems replace fossilbased products (Elghali et al., 2007). Many environmental problems seem to be omitted in several studies, and the focus is typically on climate change (Lazarevic and Martin, 2016), while environmental assessments need to have a much wider scope to be relevant (Elghali et al., 2007). Social sustainability can be better included in assessments of bio-based industrial systems. Indicators regarding employment, diversity, education and workload could be added (Buchholz et al., 2009), but they may need modification from case to case. There is a need for a set of proven and widely accepted criteria to ease decision making, and although several sets have been tried out, there is no universal set of criteria (Buchholz et al., 2009).

\subsubsection{Stakeholder importance}

Identifying and including stakeholders in the multi-criteria assessment of potential development scenarios in bio-based industrial systems was one of the contributions of this thesis. When including stakeholders, they can take part in developing what indicators should be assessed for their system, and then workshops can be held with them to gather information. The importance to identify and include relevant stakeholders for the development scenarios assessed has been acknowledged in the literature as well (Buchholz et al., 2009). Stakeholders can be either directly or indirectly involved in the activities concerning the bio-based industrial system. Possible stakeholders to include are biomass feedstock producers and suppliers; heat, electricity and biofuel project developers; utilities and fuel suppliers and end users; the financial community; technology providers; policy makers; regulators and planners; and members of the community directly affected (Elghali et al., 2007). Including many different stakeholders may inhibit the assessments by making it too time-consuming, but the knowledge which can be accessed might be important.

\subsubsection{Decision support}

Including the above aspects in assessments of bio-based industrial systems is a first step to provide broader and more relevant decision support for development scenarios. Identifying problems or potential improvement areas when biogas solutions 
are assessed is important since the biogas solutions can be applied in several ways. Applying MCA on the development scenarios is a suitable alternative to capture sustainability in complex systems, as it can reflect both quantitative and qualitative aspects as well as facilitate broader assessments and evaluation of physical and socio-economic aspects (Parajuli et al., 2015). MCA can assist in structuring a problem and thus identify what development scenarios are relevant to develop while identifying areas that are more uncertain and need further assessments in a bio-based industrial system (Buchholz et al., 2009). An assessment might not become better because it assess many aspects, and it could lead to difficulties for decision-makers to understand what is important (Feiz, 2016). Still, it is important to cover several different areas so that the focus is not on one type of problem, for example, environmental issues. The balance between necessary and optional indicators becomes important. The problem is that, as there is no universal method for assessing development scenarios in bio-based industrial systems, the results will differ between each assessment (Buchholz et al., 2009). That can be a problem for decision-makers who need to analyse the information themselves. 


\section{CONCLUSIONS AND OUTLOOK}

This chapter summarises the key findings of this thesis which may contribute to both academia and industry. There will also be some ideas for future research presented. 
This thesis has identified four main conclusions regarding, the biogas solution's contribution to sustainability in bio-based industrial systems, and decision support which can provide broader perspectives to by-product valorisation.

- Biogas solutions improve circular flows of energy and nutrients while being especially viable for low-value by-product streams.

- Biogas solutions may improve the profitability of the bio-based industrial system and contribute to development in rural areas.

- Decision support for by-product valorisation scenarios should include feasibility aspects related to contextual aspects and risks.

- The assessment of by-product valorisation scenarios is improved with stakeholder involvement, as their different perspectives strengthen the results.

These conclusions are derived from the analysis of the three appended articles and are strengthened to some extent by other literature. The relevance of biogas solutions for sustainable bio-based industrial systems is identified, as biogas solutions can serve as treatment for the industry's organic waste and waste water flows while being an energy source for internal and external use. This can reduce costs and impact from alternative solutions. The circular flows of energy and nutrients, which biogas solutions provide, are important in bio-based industrial systems. As low-value material flows can be used as substrate, the valorisation of products in bio-based industrial systems can be enhanced. Biogas solutions contribute to more circular flows, and the products can potentially replace fossil-based products and generate more income or reduce costs to the bio-based industrial system. These kinds of facilities are often situated in rural areas, and their expansion may lead to more employment and development of such areas.

However, present tools and methods for the assessment of bio-based industrial systems do often not include a wide set of external effects, or the feasibility of the systems. Such assessments should include feasibility-related aspects, for example, infrastructure readiness, regulatory support, biocascading, and public acceptance to properly assess the potential realisation of different alternatives. The identification and inclusion of stakeholders and their perspectives are relevant for the biobased industrial system's development and should be central in the assessment.

Future studies should focus on assessing biogas solutions in bio-based industrial systems to identify if the results from this thesis are general or case specific. By including alternative costs, rural development, land use, and impacts to soil, water, air and biomass, broader results can be achieved when aiming for sustainable biobased industrial systems. 


\section{REFERENCES}


Ahlgren, S., Björklund, A., Ekman, A., Karlsson, H., Berlin, J., Börjesson, P., Ekvall, T., Finnveden, G., Janssen, M., Strid, I., 2015. Review of methodological choices in LCA of biorefinery systems - key issues and recommendations. Biofuels Bioprod. Biorefining 9, 606-619. https://doi.org/10.1002/bbb.1563

Al Seadi, T., Lukehurst, C., 2012. Quality management of digestate from biogas plants used as fertiliser, in: IEA Bioenergy, Task 37.

Alburquerque, J.A., de la Fuente, C., Ferrer-Costa, A., Carrasco, L., Cegarra, J., Abad, M., Bernal, M.P., 2012. Assessment of the fertiliser potential of digestates from farm and agroindustrial residues. Biomass Bioenergy 40, 181-189. https://doi.org/10.1016/j.biombioe.2012.02.018

Andersson, V., Broberg Viklund, S., Hackl, R., Karlsson, M., Berntsson, T., 2014. Algae-based biofuel production as part of an industrial cluster. Biomass Bioenergy 71, 113-124. https://doi.org/10.1016/j.biombioe.2014.10.019

Angelidaki, I., Ahring, B.K., 1992. Effects of free long-chain fatty acids on thermophilic anaerobic digestion. Appl. Microbiol. Biotechnol. 37, 808-812. https://doi.org/10.1007/BF00174850

Arevalo-Gallegos, A., Ahmad, Z., Asgher, M., Parra-Saldivar, R., Iqbal, H.M.N., 2017. Lignocellulose: A sustainable material to produce value-added products with a zero waste approach-A review. Int. J. Biol. Macromol. 99, 308-318. https://doi.org/10.1016/j.ijbiomac.2017.02.097

Atkinson, G., Dietz, S., Neumayer, E. (Eds.), 2007. Handbook of sustainable development, Elgar original reference. Edward Elgar, Cheltenham, UK ; Northampton, MA.

Bachmann, N.E.S.A., 2013. 8 - Design and engineering of biogas plants, in: Wellinger, A., Murphy, J., Baxter, D. (Eds.), The Biogas Handbook, Woodhead Publishing Series in Energy. Woodhead Publishing, pp. 191-211.

Barbosa, D.B.P., Nabel, M., Jablonowski, N.D., 2014. Biogas-digestate as Nutrient Source for Biomass Production of Sida Hermaphrodita, Zea Mays L. and Medicago sativa L. Energy Procedia, European Geosciences Union General Assembly 2014, EGU Division Energy, Resources \& the Environment (ERE) 59, 120-126. https://doi.org/10.1016/j.egypro.2014.10.357

Batstone, D.J., Hülsen, T., Mehta, C.M., Keller, J., 2015. Platforms for energy and nutrient recovery from domestic wastewater: A review. Chemosphere, Wastewater-Energy Nexus: Towards Sustainable Wastewater Reclamation 140, 2-11. https://doi.org/10.1016/j.chemosphere.2014.10.021

Bauer, F., Persson, T., Hulteberg, C., Tamm, D., 2013. Biogas upgrading - technology overview, comparison and perspectives for the future. Biofuels Bioprod. Biorefining 7, 499-511. https://doi.org/10.1002/bbb.1423

Björnsson, L., Lantz, M., Börjesson, P., Prade, T., Svensson, S.-E., Eriksson, H., 2013. Impact of biogas energy crops on GHG emissions, soil organic matter and food crop production (No. f3 2013:27). The Swedish Knowledge Centre for Renewable Transportation Fuels. 
Börjesson, P., Berglund, M., 2007. Environmental systems analysis of biogas systems-Part II: The environmental impact of replacing various reference systems. Biomass Bioenergy 31, 326-344. https://doi.org/10.1016/j.biombioe.2007.01.004

Börjesson, P., Berglund, M., 2006. Environmental systems analysis of biogas systems-Part I: Fuel-cycle emissions. Biomass Bioenergy 30, 469-485. https://doi.org/10.1016/j.biombioe.2005.11.014

Bravo-Fritz, C.P., Sáez-Navarrete, C.A., Herrera-Zeppelin, L.A., Varas-Concha, F., 2016. Multi-scenario energy-economic evaluation for a biorefinery based on microalgae biomass with application of anaerobic digestion. Algal Res. 16, 292-307. https://doi.org/10.1016/j.algal.2016.03.028

Buchholz, T., Rametsteiner, E., Volk, T.A., Luzadis, V.A., 2009. Multi Criteria Analysis for bioenergy systems assessments. Energy Policy 37, 484-495. https://doi.org/10.1016/j.enpol.2008.09.054

Carey, D.E., Yang, Y., McNamara, P.J., Mayer, B.K., 2016. Recovery of agricultural nutrients from biorefineries. Bioresour. Technol., Waste Biorefinery - Advocating Circular Economy 215, 186-198. https://doi.org/10.1016/j.biortech.2016.02.093

Carus, M., Dammer, L., 2018. The "Circular Bioeconomy" - Concepts, Opportunities and Limitations. nova-Institut.

Cesaro, A., Belgiorno, V., 2015. Combined Biogas and Bioethanol Production: Opportunities and Challenges for Industrial Application. Energies 8, 81218144. https://doi.org/10.3390/en8088121

Chan, Y.J., Chong, M.F., Law, C.L., Hassell, D.G., 2009. A review on anaerobicaerobic treatment of industrial and municipal wastewater. Chem. Eng. J. 155, 1-18. https://doi.org/10.1016/j.cej.2009.06.041

Chen, Y., Ho, S.-H., Nagarajan, D., Ren, N., Chang, J.-S., 2018. Waste biorefineries - integrating anaerobic digestion and microalgae cultivation for bioenergy production. Curr. Opin. Biotechnol., Energy biotechnology • Environmental biotechnology 50, 101-110. https://doi.org/10.1016/j.copbio.2017.11.017

Cherubini, F., 2010. The biorefinery concept: Using biomass instead of oil for producing energy and chemicals. Energy Convers. Manag. 51, 1412-1421. https://doi.org/10.1016/j.enconman.2010.01.015

Cherubini, F., Bird, N.D., Cowie, A., Jungmeier, G., Schlamadinger, B., WoessGallasch, S., 2009. Energy- and greenhouse gas-based LCA of biofuel and bioenergy systems: Key issues, ranges and recommendations. Resour. Conserv. Recycl. 53, 434-447. https://doi.org/10.1016/j.resconrec.2009.03.013

Cordell, D., Drangert, J.-O., White, S., 2009. The story of phosphorus: Global food security and food for thought. Glob. Environ. Change, Traditional Peoples and Climate Change 19, 292-305. https://doi.org/10.1016/j.gloenvcha.2008.10.009

Costa, J.C., Sousa, D.Z., Pereira, M.A., Stams, A.J.M., Alves, M.M., 2013. Biomethanation Potential of Biological and Other Wastes, in: Gupta, V.K., Tuohy, M.G. (Eds.), Biofuel Technologies. Springer Berlin Heidelberg, pp. 369-396. 
Crolla, A., Kinsley, C., Pattey, E., 2013. Land application of digestate, in: The Biogas Handbook: Science, Production and Applications. pp. 302-325.

Dahiya, S., Kumar, A.N., Shanthi Sravan, J., Chatterjee, S., Sarkar, O., Mohan, S.V., 2018. Food waste biorefinery: Sustainable strategy for circular bioeconomy. Bioresour. Technol., Bioconversion of Food Wastes 248, 2-12. https://doi.org/10.1016/j.biortech.2017.07.176

Daroch, M., Geng, S., Wang, G., 2013. Recent advances in liquid biofuel production from algal feedstocks. Appl. Energy 102, 1371-1381. https://doi.org/10.1016/j.apenergy.2012.07.031

de Jong, E., Higson, A., Walsh, P., Wellisch, M., 2013. Bio-based chemicals, value added products from biorefineries.

Diwekar, U., 2017. An Optimization Approach to Sustainability, in: Encyclopedia of Sustainable Technologies. pp. 91-96.

Dressler, D., Loewen, A., Nelles, M., 2012. Life cycle assessment of the supply and use of bioenergy: impact of regional factors on biogas production. Int. J. Life Cycle Assess. 17, 1104-1115. https://doi.org/10.1007/s11367-0120424-9

Ekman, A., Börjesson, P., 2011. Environmental assessment of propionic acid produced in an agricultural biomass-based biorefinery system. J. Clean. Prod. 19, 1257-1265. https://doi.org/10.1016/j.jclepro.2011.03.008

Ekman, A., Wallberg, O., Joelsson, E., Börjesson, P., 2013. Possibilities for sustainable biorefineries based on agricultural residues - A case study of potential straw-based ethanol production in Sweden. Appl. Energy, Special Issue on Advances in sustainable biofuel production and use - XIX International Symposium on Alcohol Fuels - ISAF 102, 299-308. https://doi.org/10.1016/j.apenergy.2012.07.016

Elghali, L., Clift, R., Sinclair, P., Panoutsou, C., Bauen, A., 2007. Developing a sustainability framework for the assessment of bioenergy systems. Energy Policy 35, 6075-6083. https://doi.org/10.1016/j.enpol.2007.08.036

ElMekawy, A., Diels, L., De Wever, H., Pant, D., 2013. Valorization of Cereal Based Biorefinery Byproducts: Reality and Expectations. Environ. Sci. Technol. 47, 9014-9027. https://doi.org/10.1021/es402395g

European Commission, 2015. Closing the loop - An EU action plan for the Circular Economy. Brussels.

European Commission, 2012. Communication on Innovating for Sustainable Growth: A Bioeconomy for Europe. Brussels.

Feiz, R., 2016. Systems Analysis for Eco-Industrial Development : Applied on Cement and Biogas Production Systems. DIVA.

Feiz, R., Ammenberg, J., 2017. Assessment of feedstocks for biogas production, part I-A multi-criteria approach. Resour. Conserv. Recycl. https://doi.org/10.1016/j.resconrec.2017.01.019

FitzPatrick, M., Champagne, P., Cunningham, M.F., Whitney, R.A., 2010. A biorefinery processing perspective: Treatment of lignocellulosic materials for the production of value-added products. Bioresour. Technol. 101, 89158922. https://doi.org/10.1016/j.biortech.2010.06.125 
Galloway, J.N., Dentener, F.J., Capone, D.G., Boyer, E.W., Howarth, R.W., Seitzinger, S.P., Asner, G.P., Cleveland, C.C., Green, P.A., Holland, E.A., Karl, D.M., Michaels, A.F., Porter, J.H., Townsend, A.R., Vöosmarty, C.J., 2004. Nitrogen Cycles: Past, Present, and Future. Biogeochemistry 70, 153-226. https://doi.org/10.1007/s10533-004-0370-0

Girotto, F., Alibardi, L., Cossu, R., 2015. Food waste generation and industrial uses: A review. Waste Manag., Urban Mining 45, 32-41. https://doi.org/10.1016/j.wasman.2015.06.008

Giwa, A., Adeyemi, I., Dindi, A., Lopez, C.G.-B., Lopresto, C.G., Curcio, S., Chakraborty, S., 2018. Techno-economic assessment of the sustainability of an integrated biorefinery from microalgae and Jatropha: A review and case study. Renew. Sustain. Energy Rev. 88, 239-257. https://doi.org/10.1016/j.rser.2018.02.032

González-García, S., Hospido, A., Agnemo, R., Svensson, P., Selling, E., Moreira, M.T., Feijoo, G., 2011. Environmental Life Cycle Assessment of a Swedish Dissolving Pulp Mill Integrated Biorefinery. J. Ind. Ecol. 15, 568-583. https://doi.org/10.1111/j.1530-9290.2011.00354.x

González-García, S., Lacoste, C., Aicher, T., Feijoo, G., Lijó, L., Moreira, M.T., 2016. Environmental sustainability of bark valorisation into biofoam and syngas. J. Clean. Prod. 125, 33-43. https://doi.org/10.1016/j.jclepro.2016.03.024

Gullón, P., Gullón, B., Dávila, I., Labidi, J., Gonzalez-Garcia, S., 2018. Comparative environmental Life Cycle Assessment of integral revalorization of vine shoots from a biorefinery perspective. Sci. Total Environ. 624, 225-240. https://doi.org/10.1016/j.scitotenv.2017.12.036

Haberl, R., Atanasoff, K., Braun, R., 1991. Anaerobic-Aerobic Treatment of Organic High-Strength Industrial Waste Water. Water Sci. Technol. 23, 19091918.

Haddadi, M.H., Aiyelabegan, H.T., Negahdari, B., 2018. Advanced biotechnology in biorefinery: a new insight into municipal waste management to the production of high-value products. Int. J. Environ. Sci. Technol. 15, 675-686. https://doi.org/10.1007/s13762-017-1424-X

Hagman, L., Eklund, M., 2016. The role of biogas solutions in the circular and biobased economy. Published by Biogas Öst.

Hansen, K.H., Angelidaki, I., Ahring, B.K., 1998. Anaerobic digestion of swine manure: Inhibition by ammonia. Water Res. 32, 5-12. https://doi.org/10.1016/S0043-1354(97)00201-7

Haug, R., 2018. The Practical Handbook of Compost Engineering. Routledge.

Höltinger, S., Schmidt, J., Schönhart, M., Schmid, E., 2014. A spatially explicit techno-economic assessment of green biorefinery concepts. Biofuels Bioprod. Biorefining 8, 325-341. https://doi.org/10.1002/bbb.1461

Huang, I.B., Keisler, J., Linkov, I., 2011. Multi-criteria decision analysis in environmental sciences: Ten years of applications and trends. Sci. Total Environ. 409, 3578-3594. https://doi.org/10.1016/j.scitotenv.2011.06.022

ISO, 2006. ISO 14040:2006 - Environmental management -- Life cycle assessment -- Principles and framework. 
Joelsson, E., Wallberg, O., Börjesson, P., 2015. Integration potential, resource efficiency and cost of forest-fuel-based biorefineries. Comput. Chem. Eng. 82, 240-258. https://doi.org/10.1016/j.compchemeng.2015.07.011

Ju, I., Wj, B., Md, S., Ia, O., Oj, E., 2018. A review: Biofertilizer - A key player in enhancing soil fertility and crop productivity. J. Microbiol. Biotechnol. Rep. 2.

Kamali, M., Khodaparast, Z., 2015. Review on recent developments on pulp and paper mill wastewater treatment. Ecotoxicol. Environ. Saf. 114, 326-342. https://doi.org/10.1016/j.ecoenv.2014.05.005

Kamm, B., Kamm, M., 2007. International biorefinery systems. Pure Appl. Chem. 79, 1983-1997. https://doi.org/10.1351/pac200779111983

Keller, H., Rettenmaier, N., Reinhardt, G.A., 2015. Integrated life cycle sustainability assessment - A practical approach applied to biorefineries. Appl. Energy 154, 1072-1081. https://doi.org/10.1016/j.apenergy.2015.01.095

Kloepffer, W., 2008. Life cycle sustainability assessment of products. Int. J. Life Cycle Assess. 13, 89. https://doi.org/10.1065/lca2008.02.376

Kouhia, M., Holmberg, H., Ahtila, P., 2015. Microalgae-utilizing biorefinery concept for pulp and paper industry: Converting secondary streams into valueadded products. Algal Res. 10, 41-47. https://doi.org/10.1016/j.algal.2015.04.001

Kouřimská, L., Poustková, I., Babička, L., 2012. The use of digestate as a replacement of mineral fertilizers for vegetables growing. Sci. Agric. Bohem. 43, 121-126. https://doi.org/10.7160/sab.2012.430401

Langeveld, H., Sanders, J., Meeusen, M., 2012. The Biobased Economy: Biofuels, Materials, and Chemicals in the Post-oil Era. Earthscan.

Lardy, G., Anderson, V., 2014. Feeding Coproducts of the Ethanol Industry to Beef Cattle.

Lazarevic, D., Martin, M., 2016. Life cycle assessments, carbon footprints and carbon visions: Analysing environmental systems analyses of transportation biofuels in Sweden. J. Clean. Prod. 137, 249-257.

https://doi.org/10.1016/j.jclepro.2016.07.075

Li, -., Noike, T., 1992. Upgrading of anaerobic digestion of waste activated sludge by thermal pretreatment. Water Sci. Technol. 26, 857-866.

Lorenzi, G., Baptista, P., 2018. Promotion of renewable energy sources in the Portuguese transport sector: A scenario analysis. J. Clean. Prod. 186, 918-932. https://doi.org/10.1016/j.jclepro.2018.03.057

Luo, L., van der Voet, E., Huppes, G., 2010. Biorefining of lignocellulosic feedstock - Technical, economic and environmental considerations. Bioresour. Technol., Special Issue on Lignocellulosic Bioethanol: Current Status and Perspectives 101, 5023-5032. https://doi.org/10.1016/j.biortech.2009.12.109

Martin, M., Eklund, M., 2011. Improving the environmental performance of biofuels with industrial symbiosis. Biomass Bioenergy 35, 1747-1755. https://doi.org/10.1016/j.biombioe.2011.01.016 
Martin, M., Parsapour, A., 2012. Upcycling wastes with biogas production: An exergy and economic analysis, in: Venice 2012: International Symposium on Energy from Biomass and Waste.

Martinez, G.A., Rebecchi, S., Decorti, D., Domingos, J.M.B., Natolino, A., Rio, D.D., Bertin, L., Porto, C.D., Fava, F., 2015. Towards multi-purpose biorefinery platforms for the valorisation of red grape pomace: production of polyphenols, volatile fatty acids, polyhydroxyalkanoates and biogas. Green Chem. 18, 261-270. https://doi.org/10.1039/C5GC01558H

Martinez Hernandez, E., 2013. Process integration, economic and environmental analysis tools for biorefinery design (Ph.D.). University of Manchester.

Möller, K., Müller, T., 2012. Effects of anaerobic digestion on digestate nutrient availability and crop growth: A review. Eng. Life Sci. 12, 242-257. https://doi.org/10.1002/elsc.201100085

Mountraki, A., Tsakalova, M., Panteli, A., Papoutsi, A.I., Kokossis, A.C., 2016. Integrated Waste Management in Multiproduct Biorefineries: Systems Optimization and Analysis of a Real-Life Industrial Plant. Ind. Eng. Chem. Res. 55, 3478-3492. https://doi.org/10.1021/acs.iecr.5b03431

Munda, G., Nijkamp, P., Rietveld, P., 1994. Qualitative multicriteria evaluation for environmental management. Ecol. Econ. 10, 97-112. https://doi.org/10.1016/0921-8009(94)90002-7

Murphy, J.D., McKeogh, E., Kiely, G., 2004. Technical/economic/environmental analysis of biogas utilisation. Appl. Energy 77, 407-427. https://doi.org/10.1016/j.apenergy.2003.07.005

Mussgnug, J.H., Klassen, V., Schlüter, A., Kruse, O., 2010. Microalgae as substrates for fermentative biogas production in a combined biorefinery concept. J. Biotechnol. 150, 51-56. https://doi.org/10.1016/j.jbiotec.2010.07.030

Nitzsche, R., Budzinski, M., Gröngröft, A., 2016. Techno-economic assessment of a wood-based biorefinery concept for the production of polymer-grade ethylene, organosolv lignin and fuel. Bioresour. Technol. 200, 928-939. https://doi.org/10.1016/j.biortech.2015.11.008

NL Government, 2016. From a linear to a circular economy - Circular economy Government.nl [Online]. URL https:/www.government.nl/topics/circulareconomy/from-a-linear-to-a-circular-economy (accessed 10.10.18).

Olsson, L., Fallde, M., 2015. Waste(d) potential: a socio-technical analysis of biogas production and use in Sweden. J. Clean. Prod., Special Volume: Support your future today! Turn environmental challenges into opportunities. 98, 107-115. https://doi.org/10.1016/j.jclepro.2014.02.015

Orts, W.J., McMahan, C.M., 2016. Biorefinery Developments for Advanced Biofuels from a Sustainable Array of Biomass Feedstocks: Survey of Recent Biomass Conversion Research from Agricultural Research Service. BioEnergy Res. 9, 430-446. https://doi.org/10.1007/s12155-016-9732-4

Parajuli, R., Dalgaard, T., Jørgensen, U., Adamsen, A.P.S., Knudsen, M.T., Birkved, M., Gylling, M., Schjørring, J.K., 2015. Biorefining in the prevailing energy and materials crisis: a review of sustainable pathways for biorefinery value chains and sustainability assessment methodologies. Renew. 
Sustain. $\quad$ Energy $\quad$ Rev. 43, 244-263. https://doi.org/10.1016/j.rser.2014.11.041

Paul Arwas Associates, 2005. Biomass sector review for the Carbon Trust. UK.

Pereira, C.P.P., Slingerland, M.A., Lier, J.B. van, Rabbinge, R., 2013. Anaerobic digestion as a key technology for biomass valorization: contribution to the energy balance of biofuel chains, in: The Biogas Handbook: Science, Production and Applications. Woodhead Publishing, pp. 166-188.

Pérez-Camacho, M.N., Curry, R., 2017. Regional assessment of bioeconomy options using the anaerobic biorefinery concept. Proc. Inst. Civ. Eng. - Waste Resour. Manag. 1-10. https://doi.org/10.1680/jwarm.17.00015

Pfaltzgraff, L.A., Bruyn, M.D., Cooper, E.C., Budarin, V., Clark, J.H., 2013. Food waste biomass: a resource for high-value chemicals. Green Chem. 15, 307314. https://doi.org/10.1039/C2GC36978H

Posada, J.A., Osseweijer, P., 2016. Chapter 26 - Socioeconomic and Environmental Considerations for Sustainable Supply and Fractionation of Lignocellulosic Biomass in a Biorefinery Context, in: Mussatto, S.I. (Ed.), Biomass Fractionation Technologies for a Lignocellulosic Feedstock Based Biorefinery. Elsevier, Amsterdam, pp. 611-631.

Prade, T., Kätterer, T., Björnsson, L., 2017. Including a one-year grass ley increases soil organic carbon and decreases greenhouse gas emissions from cereal-dominated rotations - A Swedish farm case study. Biosyst. Eng. 164, 200-212. https://doi.org/10.1016/j.biosystemseng.2017.10.016

Qadeer, S., Mahmood, S., Anjum, M., Ilyas, N., Ali, Z., Khalid, A., 2018. Synchronization of lipid-based biofuel production with waste treatment using oleaginous bacteria: A biorefinery concept. Process Saf. Environ. Prot. 115, 99-107. https://doi.org/10.1016/j.psep.2017.10.011

Rantala, P., Väänänen, P., 1985. Cost Comparison of Aerobic and Anaerobic Wastewater Treatment Systems. Water Sci. Technol. 17, 255-255.

Ravina, M., Genon, G., 2015. Global and local emissions of a biogas plant considering the production of biomethane as an alternative end-use solution. J. Clean. Prod. 102, 115-126. https://doi.org/10.1016/j.jclepro.2015.04.056

Risberg, K., Cederlund, H., Pell, M., Arthurson, V., Schnürer, A., 2017. Comparative characterization of digestate versus pig slurry and cow manure Chemical composition and effects on soil microbial activity. Waste Manag. 61, 529-538. https://doi.org/10.1016/j.wasman.2016.12.016

Sauvée, L., Viaggi, D., 2016. Biorefineries in the bio-based economy: opportunities and challenges for economic research. Bio-Based Appl. Econ. 5, 1-4.

Sawatdeenarunat, C., Nguyen, D., Surendra, K.C., Shrestha, S., Rajendran, K., Oechsner, H., Xie, L., Khanal, S.K., 2016. Anaerobic biorefinery: Current status, challenges, and opportunities. Bioresour. Technol. 2016. https://doi.org/10.1016/j.biortech.2016.03.074

Schmidell, W., Craveiro, A.M., Peres, C.S., Hirata, Y.S., Varella, R.F., 1986. Anaerobic Digestion of Municipal Solid Wastes. Water Sci. Technol. 18, 163175.

Shakeri Yekta, S., Ziels, R.M., Björn, A., Skyllberg, U., Ejlertsson, J., Karlsson, A., Svedlund, M., Willen, M., Svensson, B., 2017. Importance of sulfide 
interaction with iron as regulator of the microbial community in biogas reactors and its effect on methanogenesis, volatile fatty acids turnover, and syntrophic long-chain fatty acids degradation. J. Biosci. Bioeng. 123, 597605.

Sonnenberg, A., Baars, J., Hendrickx, P., 2007. IEA Bioenergy Task 42 Biorefinery.

Surendra, K. c., Sawatdeenarunat, C., Shrestha, S., Sung, S., Khanal, S.K., 2015. Anaerobic Digestion-Based Biorefinery for Bioenergy and Biobased Products. Ind. Biotechnol. 11, 103-112. https://doi.org/10.1089/ind.2015.0001

Tambone, F., Scaglia, B., D’Imporzano, G., Schievano, A., Orzi, V., Salati, S., Adani, F., 2010. Assessing amendment and fertilizing properties of digestates from anaerobic digestion through a comparative study with digested sludge and compost. Chemosphere 81, 577-583.

https://doi.org/10.1016/j.chemosphere.2010.08.034

Thompson, G., Swain, J., Kay, M., Forster, C.F., 2001. The treatment of pulp and paper mill effluent: a review. Bioresour. Technol. 77, 275-286. https://doi.org/10.1016/S0960-8524(00)00060-2

Tufvesson, L.M., Lantz, M., Börjesson, P., 2013. Environmental performance of biogas produced from industrial residues including competition with animal feed - life-cycle calculations according to different methodologies and standards. J. Clean. Prod. 53, 214-223. https://doi.org/10.1016/j.jclepro.2013.04.005

Turcksin, L., Macharis, C., Lebeau, K., Boureima, F., Van Mierlo, J., Bram, S., De Ruyck, J., Mertens, L., Jossart, J.-M., Gorissen, L., Pelkmans, L., 2011. A multi-actor multi-criteria framework to assess the stakeholder support for different biofuel options: The case of Belgium. Energy Policy 39, 200-214. https://doi.org/10.1016/j.enpol.2010.09.033

Vaccari, D.A., 2009. Phosphorus: A Looming Crisis. Sci. Am. 300, 54-59. https://doi.org/10.1038/scientificamerican0609-54

Vaneeckhaute, C., Styles, D., Prade, T., Adams, P., Thelin, G., Rodhe, L., Gunnarsson, I., D'Hertefeldt, T., 2018. Closing nutrient loops through decentralized anaerobic digestion of organic residues in agricultural regions: A multi-dimensional sustainability assessment. Resour. Conserv. Recycl. 136, 110-117. https://doi.org/10.1016/j.resconrec.2018.03.027

Wagemann, K., 2012. Biorefineries - Prerequisite for the realization of a future bioeconomy. Presented at the DGMK Tagungsbericht, pp. 133-143.

WCED, 1987. Our common future. Oxford University Press., Oxford.

Wellinger, A., Murphy, J., Baxter, D. (Eds.), 2013. The biogas handbook: Science, production and applications. Woodhead.

Wentzel, S., Joergensen, R.G., 2016. Effects of biogas and raw slurries on grass growth and soil microbial indices. J. Plant Nutr. Soil Sci. 179, 215-222. https://doi.org/10.1002/jpln.201400544

Westerholm, M., Isaksson, S., Karlsson Lindsjö, O., Schnürer, A., 2018. Microbial community adaptability to altered temperature conditions determines the potential for process optimisation in biogas production. Appl. Energy 226, 838-848. https://doi.org/10.1016/j.apenergy.2018.06.045 
Witing, F., Prays, N., O’Keeffe, S., Gründling, R., Gebel, M., Kurzer, H.-J., Daniel-Gromke, J., Franko, U., 2018. Biogas production and changes in soil carbon input - A regional analysis. Geoderma 320, 105-114. https://doi.org/10.1016/j.geoderma.2018.01.030

Wood, B.M., Jader, L.R., Schendel, F.J., Hahn, N.J., Valentas, K.J., Mcnamara, P.J., Novak, P.M., Heilmann, S.M., 2013. Industrial symbiosis: Corn ethanol fermentation, hydrothermal carbonization, and anaerobic digestion. Biotechnol. Bioeng. 110, 2624-2632. https://doi.org/10.1002/bit.24924

Zhang, W., Alvarez-Gaitan, J., Dastyar, W., Saint, C., Zhao, M., Short, M., Zhang, W., Alvarez-Gaitan, J.P., Dastyar, W., Saint, C.P., Zhao, M., Short, M.D., 2018. Value-Added Products Derived from Waste Activated Sludge: A Biorefinery Perspective. Water 10, 545. https://doi.org/10.3390/w10050545 


\section{APPENDIX}

"Be the change that you wish to see in the world."

- Mahatma Gandhi 



\section{Appended Papers}

The appended papers associated with this thesis have been removed for copyright reasons. For more details about these see:

$\underline{\text { http://urn.kb.se/resolve?urn=urn:nbn:se:liu:diva-152878 }}$ 